\title{
Cell cycle alterations induced by urban PM2.5 in bronchial epithelial cells: characterization of the process and possible mechanisms involved
}

Eleonora Longhin ${ }^{1 * \dagger}$, Jørn A Holme ${ }^{2+}$, Kristine B Gutzkow ${ }^{2}$, Volker M Arlt ${ }^{3}$, Jill E Kucab ${ }^{3}$, Marina Camatini ${ }^{1}$ and Maurizio Gualtieri ${ }^{1+}$

\begin{abstract}
Background: This study explores and characterizes cell cycle alterations induced by urban PM2.5 in the human epithelial cell line BEAS-2B, and elucidates possible mechanisms involved.

Methods: The cells were exposed to a low dose $\left(7.5 \mu \mathrm{g} / \mathrm{cm}^{2}\right)$ of Milan winter PM2.5 for different time points, and the cell cycle progression was analyzed by fluorescent microscopy and flow cytometry. Activation of proteins involved in cell cycle control was investigated by Western blotting and DNA damage by ${ }^{32}$ P-postlabelling, immunostaining and comet assay. The formation of reactive oxygen species (ROS) was quantified by flow cytometry. The role of PM organic fraction versus washed PM on the cell cycle alterations was also examined. Finally, the molecular pathways activated were further examined using specific inhibitors.

Results: Winter PM2.5 induced marked cell cycle alteration already after $3 \mathrm{~h}$ of exposure, represented by an increased number of cells (transient arrest) in G2. This effect was associated with an increased phosphorylation of Chk2, while no changes in p53 phosphorylation were observed at this time point. The increase in G2 was followed by a transient arrest in the metaphase/anaphase transition point $(10 \mathrm{~h})$, which was associated with the presence of severe mitotic spindle aberrations. The metaphase/anaphase delay was apparently followed by mitotic slippage at $24 \mathrm{~h}$, resulting in an increased number of tetraploid G1 cells and cells with micronuclei (MN), and by apoptosis at $40 \mathrm{~h}$. Winter PM2.5 increased the level of ROS at $2 \mathrm{~h}$ and DNA damage (8-oxodG, single- and double stand breaks) was detected after $3 \mathrm{~h}$ of exposure. The PM organic fraction caused a similar G2/M arrest and augmented ROS formation, while washed PM had no such effects. DNA adducts were detected after 24 h. Both PM-induced DNA damage and G2 arrest were inhibited by the addition of antioxidants and a-naphthoflavone, suggesting the involvement of ROS and reactive electrophilic metabolites formed via a P450-dependent reaction.
\end{abstract}

Conclusions: Milan winter PM2.5 rapidly induces severe cell cycle alterations, resulting in increased frequency of cells with double nuclei and MN. This effect is related to the metabolic activation of PM2.5 organic chemicals, which cause damages to DNA and spindle apparatus.

Keywords: PM2.5, BEAS-2B, Mitotic arrest, CYP enzymes, ROS

\footnotetext{
*Correspondence: e.longhin1@campus.unimib.it

†'Equal contributors

'Department of Environmental Sciences, POLARIS Research Centre, University

Milano-Bicocca, Piazza della Scienza 1, 20126 Milano, Italy

Full list of author information is available at the end of the article
} 


\section{Background}

In October 2013 the International Agency for Research on Cancer (IARC) classified outdoor air pollution as carcinogenic to humans (Group 1) [1]. Particulate matter (PM) is a well-known air pollutant and its adverse effects on human health are well established [2,3]. Increased levels of PM have been associated with exacerbation of airways disease in patients with asthma and Chronic Obstructive Pulmonary Disease (COPD) [4]. There is growing evidence linking long-term exposure to the fine PM fraction (PM2.5; aerodynamic diameter $\leq 2.5 \mu \mathrm{m}$ ) with increased risk of cardiovascular mortality $[5,6]$ and lung cancer $[7,8]$. However, the understanding of the mechanisms by which PM exerts its various adverse effects is still incomplete and detailed in vitro studies are highly needed.

Urban air PM is a heterogeneous mixture of various types of particles originating from different sources. Combustion particles emitted from vehicles consist mainly of spherical primary carbon particles with diameters ranging from 20 to $30 \mathrm{~nm}$, which tend to aggregate in PM1 and PM2.5 $[9,10]$. The small diameters of the primary carbon particles provide a relatively high surface area per mass unit, which facilitates the adsorption of various components to the particles, including metals, organic compounds and biological components like bacterial endotoxins $[11,12]$. In contrast, larger size particles as PM10 often are found to be arbitrarily-shaped mineral particles from road wear and soil dusts [13]. The composition of urban air PM also varies with season, and all these variables have a primary role in the promotion of the biological effects. This is evidenced by in vitro studies showing that, depending on composition, PM can trigger release of inflammatory mediators including various cytokines and chemokines [11,14], genotoxic effects [15-17] and cell death $[11,18]$.

In vitro studies have demonstrated that PM may inhibit cell growth, by reducing proliferation and/or causing cell death [19-21]. The reduced proliferation has been linked to an arrest in various steps of the cell cycle [20-23]. Cell cycle progression can be blocked and/or delayed in response to various genotoxic stresses, but also to structural dysfunctions of various proteins. DNA-integrity checkpoints G1/S, G2/M and metaphaseanaphase $(\mathrm{M} / \mathrm{A})$ transition determine delays of the cell cycle $[24,25]$. The protein kinases ATM (ataxia telangiectasia mutated) and ATR (ATM and Rad3 related) contribute to the DNA damage response and activate the checkpoint protein kinases Chk1/2, which may result in cell cycle arrest by a p53-dependent or -independent pathway [26]. Both of these pathways regulate the activity of $\mathrm{G} 1 / \mathrm{S}$ or $\mathrm{G} 2 / \mathrm{M}$ transition promoters cyclindependent kinase (Cdk)/cyclin, such as Cdk1/cyclin B1, which drives the progression from $\mathrm{G} 2$ to the mitotic phase $[26,27]$. In the p53-dependent pathway, Chk1/2 phosphorylates p53 (Ser 15) which, through the transcriptional activation of downstream mediators p21 and 14-3-3, inhibits Cdk1/cyclin B1. In the p53-independent pathway, Chk1/2 phosphorylates Cdc25 and Wee-1, which cooperatively reduce $\mathrm{Cdk} 1 /$ cyclin $\mathrm{B} 1$ activity, leading to G2 arrest and preventing entry into mitosis [28].

The passage from metaphase to anaphase (M/A transition point) requires the disassembling of the $\mathrm{Cdk} 1 /$ cyclin B1 complex. The anaphase-promoting complex (APC) is responsible for the ubiquitination and subsequent degradation of cyclin B1 [29]. The spindle assembly checkpoint $(\mathrm{SAC})$ acts on the mitosis delay at the M/A transition point, preventing the activation of APC until the mitotic spindle is correctly formed [26,30]. The inhibition of APC by SAC results in the stabilization of cyclin B1, which prevents the anaphase onset and karyokinesis until all chromosomes are properly attached to the bipolar mitotic spindle [29,31]. If the spindle is not properly attached to the chromosomes within a defined time period, the cell may enter a death process or may exit from mitosis without dividing the genetic material, a process named mitotic slippage. Cell death during mitosis or after mitotic slippage is termed mitotic catastrophe, an atypical mode of cell death, which often is due to premature or inappropriate entry into mitosis [29]. An abnormal spindle structure can be a consequence of DNA damage or can be directly originated by spindlepoisons. Thus, the identification of the specific stage at which a particular agent inhibits cell cycle progression, through the G1/S, G2/M or M/A transition points, has a pivotal role in the understanding of the mechanisms as well the final outcome.

Recently we have observed that exposure to $25 \mu \mathrm{g} / \mathrm{cm}^{2}$ of Milan winter PM2.5 for $20 \mathrm{~h}$ induced a mitotic arrest resulting in cell death by apoptosis in human bronchial epithelial cells (BEAS-2B) [21]. Effects involved in DNA-damage response, such as $\gamma \mathrm{H} 2 \mathrm{AX}$ and Chk2 overexpression, were detected at the low doses 5 and $7.5 \mu \mathrm{g} / \mathrm{cm}^{2}$. A further characterization of PM-induced cell cycle and mitotic alterations is important when trying to explain PM-induced chromosomal alterations, as well as its association with an increased risk of lung cancer $[1,7,8]$.

In the present study, the effects of Milan winter PM2.5 on the cell cycle progression were characterized using the low dose $7.5 \mu \mathrm{g} / \mathrm{cm}^{2}$. This dose rapidly induced a delay in G2 phase, which was followed by a specific arrest at the $\mathrm{M} / \mathrm{A}$ transition point and by an increased number of cells with double nuclei and micronuclei $(\mathrm{MN})$. The proteins controlling the cell cycle process were investigated by Western blotting and the presence of mitotic spindle aberrations by fluorescence microscopy. The PM organic fraction 
and washed PM were tested to explore their role in the induced alterations. We further measured the formation of reactive oxygen species (ROS) and possible damage to the mitochondria and DNA. Finally, antioxidants and the AhR/ CYP enzymes inhibitor alpha-naphthoflavone ( $\alpha$-NF) were used to investigate the importance of ROS and/or P450catalyzed metabolites for PM-induced cell cycle alterations.

Our results indicate that the observed effects were associated with chemicals in the PM organic fraction. Using inhibitors and antioxidants, we showed that these compounds were activated via CYP enzymes to reactive electrophilic and/or radical metabolites which induced
DNA damage and likely affected the chromosomal spindle apparatus.

\section{Results}

Cell cycle alterations in cells exposed to winter PM2.5

In preliminary studies we found that Milan winter PM2.5 induced a slight decrease in BEAS-2B cell proliferation, evidenced by microscopic observations, but no significant cell death (Figure 1A). To examine if the reduced proliferation was due to cell cycle alterations and consequent accumulation of cells at a specific cell cycle phase, cells were analysed at different time points by

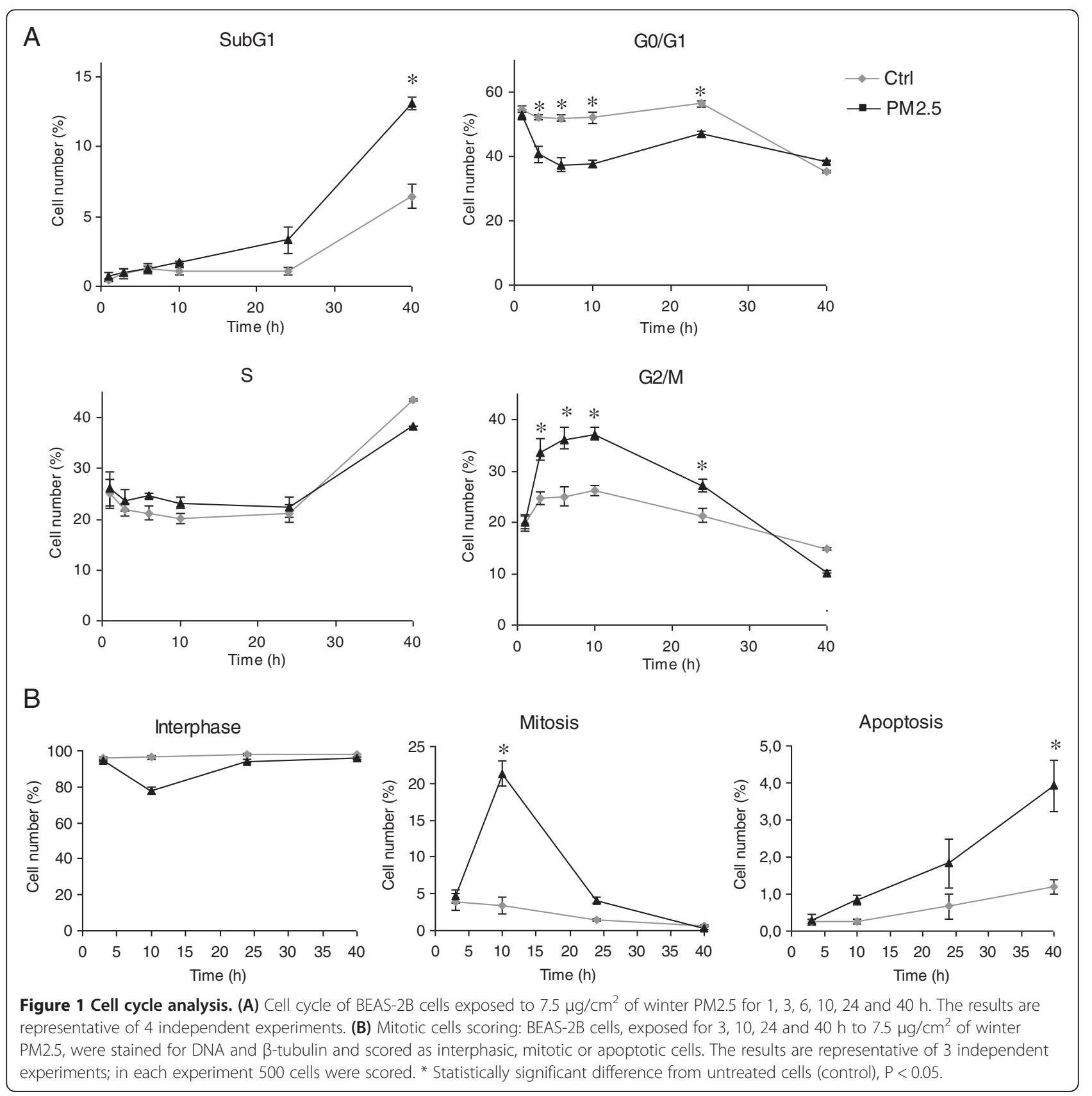


flow cytometry. Figure 1A illustrates an increase in the number of $\mathrm{G} 2 / \mathrm{M}$ cells in the time interval from 3 to $24 \mathrm{~h}$. After $3 \mathrm{~h}$ of PM-treatment, the number of G2/M cells was $33.5 \%$ compared to $24.7 \%$ in controls. The relative distribution of cells returned to the control values after $40 \mathrm{~h}$ of exposure. At this time point, a significant increase of subG1 cells (13.2\% in PM exposed samples versus $6.5 \%$ in controls), representing cells with DNA < $2 \mathrm{~N}$ (possibly apoptotic and apoptotic/necrotic cells), was observed (Figure 1A).

In order to further characterize the G2/M arrest, and the subsequent subG1 increase, the amount of mitotic and apoptotic cells was screened by fluorescence microscopy at $3,10,24$ and $40 \mathrm{~h}$ of exposure. Cells were stained for DNA and $\beta$-tubulin and scored according to nucleus and spindle morphology as interphasic, mitotic or apoptotic. At $3 \mathrm{~h}$, in PM-treated samples the relative amount of mitotic cells (with evident chromosome condensation) was similar to controls (Figure 1B), suggesting that the $\mathrm{G} 2 / \mathrm{M}$ increase was due to an accumulation of cells at the G2/M checkpoint. However, at $10 \mathrm{~h}$ a dramatic increase in the relative number of mitotic cells was observed $(21.3 \%$ in treated cells versus $3.3 \%$ in controls). Interestingly, after $24 \mathrm{~h}$ the percentage of mitotic cells in exposed samples returned to control levels, without any marked change in the relative amount of necrotic and/or apoptotic cells until $40 \mathrm{~h}$ of treatment (Figure 1A and B), when a significant increase in apoptotic cells was observed.

\section{Cell cycle control}

The mechanism leading to cell cycle alterations was investigated by analysing the expression and phosphorylation (activation) of two key proteins, p53 and Chk2, involved in the control of G2 checkpoint activation [26].

The results obtained by Western blotting showed a significant increase in the levels of pChk2 in cells treated with winter PM2.5 for $3 \mathrm{~h}$ (Figure 2); after $10 \mathrm{~h}$ of exposure, the levels of pChk2 returned to control values. Interestingly, neither the level of p53 nor its phosphorylated form were increased after PM treatments at 3 and $10 \mathrm{~h}$ (Figure 2); however significant increases of both forms were observed in cells exposed to the positive control topoisomerase II inhibitor etoposide.

\section{Characterization of the mitotic process}

Cells arrested in mitosis were further characterized by fluorescence microscopy in order to determine if structural modifications of the mitotic spindle could be responsible for the observed mitotic arrest. In cultures exposed to PM2.5 for $10 \mathrm{~h}$, post-anaphase (anaphase and telophase) was seen only in $4 \%$ of the mitotic cells compared to $31 \%$ in controls (Figure 3). The mitotic cells in PM exposed samples seemed to be arrested at the M/A transition point, suggesting alterations of the mitotic spindle apparatus. This imbalance among the mitosis phases was maintained at 24 and $40 \mathrm{~h}$. Indeed, although the number of mitotic cells was comparable in controls and PM-treated samples, the relative count of pre- and post-anaphase cells still showed significant differences.

Aberrations of the mitotic spindle, represented by tripolar (Figure 4A), multipolar (Figure 4C) and incomplete (Figure 4B) spindles, were also observed. Tripolar spindles accounted for $8 \%$ of mitotic cells in PMexposed samples compared to $2 \%$ in controls. Anaphasic and telophasic tripolar cells were also observed, suggesting that some of these cells were able to complete the mitotic division (Figure 4A). Incomplete spindles were represented by bipolar spindles with groups of lagging chromosomes (Figure 4B). This configuration occurred in approximately $10 \%$ of mitotic cells in treated samples compared to $1 \%$ of controls. Cells stained for $\gamma$-tubulin evidenced the presence of centrosome amplification associated with multipolar spindles (Figure 4C). Cells with more than 3 centrosomes represented $6.7 \%$ of mitotic cells in exposed samples compared to $2.7 \%$ in controls. Post-anaphase cells with incomplete and multipolar spindles were never observed.

Since cyclin B1, associated with Cdk1, drives the progression of cells through mitosis, its level was analysed with flow cytometry. A significantly higher level of this protein was detected in cells exposed to PM for 10 and 24 h compared to controls (Figure 5A).

Finally, fluorescence microscopy analysis after $24 \mathrm{~h}$ of PM exposure showed cells with large abnormal nuclei and others with double-nuclei, while cells with $\mathrm{MN}$ were detected in $18.8 \%$ of treated samples compared to $3.2 \%$ of controls (Figure 5B). These findings suggest that the mitotic block often resulted in impaired cytokinesis and/ or disturbed chromosomal separation.

\section{PM components responsible for G2/M delay}

To further study which PM components could be responsible for the observed effects, the organic compounds were extracted from particles; both this organic fraction and the washed particles were tested for cell cycle alterations. The G2/M increase induced after 3 and $10 \mathrm{~h}$ of exposure to PM organic fraction was higher than that observed in the whole-PM exposed cells, while the washed particles were ineffective (Figure 6). Interestingly after $24 \mathrm{~h}$ of exposure, when an increase in G2/M phase was still observed in whole-PM treated cells, an increased number of cells in G1 was seen after exposure to PM organic fraction and this increase could still be observed after $40 \mathrm{~h}$ of exposure. At this time point, an increased amount of cells in subG1 following exposure to whole-PM was seen (Figure 6). 

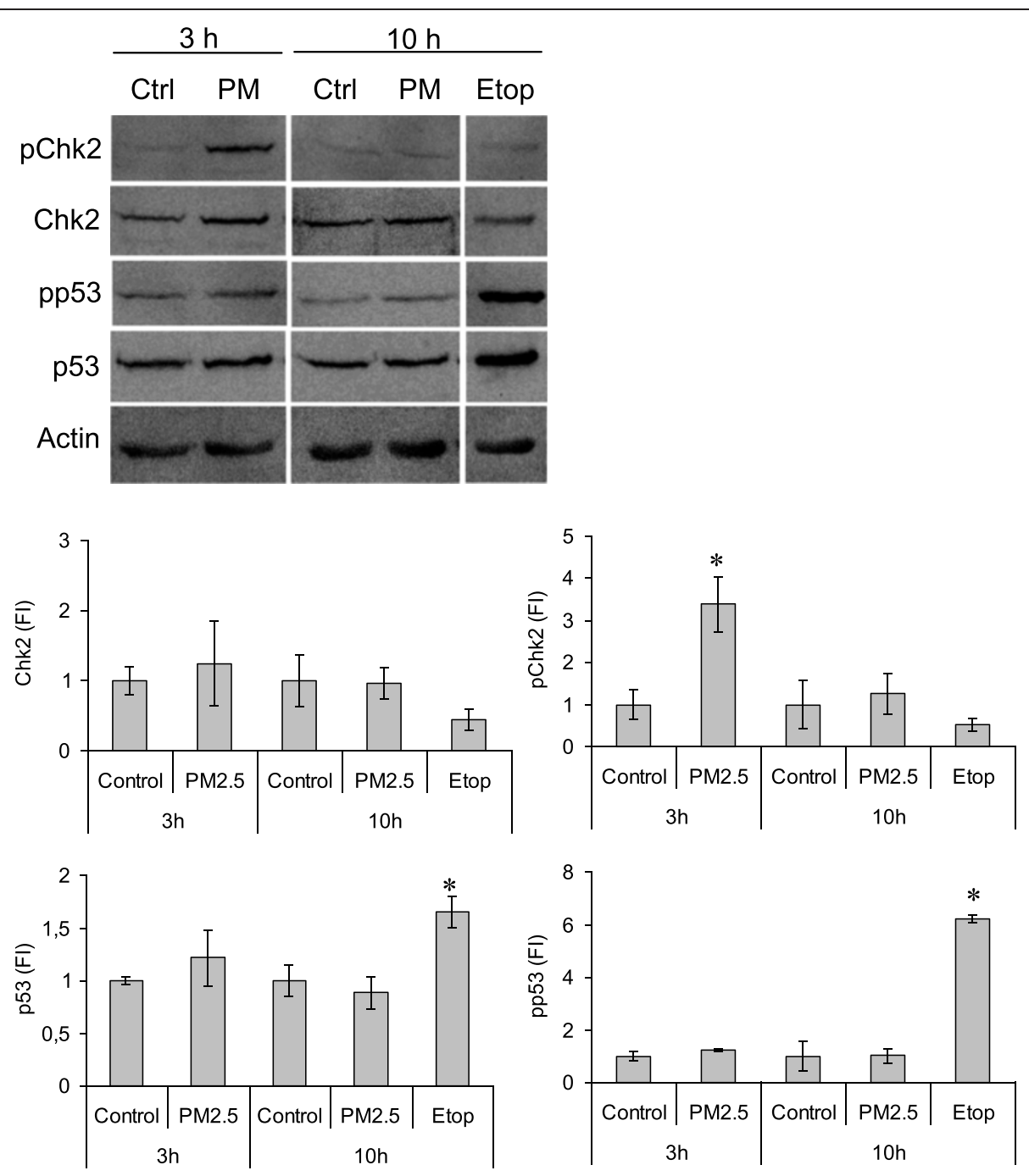

Figure 2 Cell cycle control proteins expression. The expression of p53/pp53 and Chk2/pChk2, proteins possibly involved in G2 checkpoint, was measured by Western blotting in BEAS-2B cells exposed for 3 and $10 \mathrm{~h}$ to $7.5 \mu \mathrm{g} / \mathrm{cm}^{2}$ of winter PM2.5. The topoisomerase II inhibitor etoposide (Etop, $250 \mathrm{nM}, 10 \mathrm{~h}$ exposure) was used as positive control for p53/pp53. Representative images of the Western blotting are shown and the results of 3 independent experiments are reported in the histograms as fold increase (FI) over the control values (mean \pm SEM). *Statistically significant difference from untreated cells (control), $P<0.05$.

\section{Cellular mechanisms involved in G2/M delay}

ROS formation in treated BEAS-2B cells was analysed to investigate their possible involvement in the induction of the transient G2/M arrest. Notably, the PM organic fraction induced higher levels of ROS in comparison with whole$\mathrm{PM}$, resulting in a 2.4-fold increase of fluorescence intensity (22.5 a.u. in exposed cells versus 9.2 a.u. in controls). Washed particles were ineffective (Figure 7).

Mitochondria are known sources for ROS formation [32], thus their possible role in PM-induced ROS was investigated. First, the co-localization of ROS and mitochondria in cells was assessed by staining with DCFHDA and MitoTracker, respectively. The results showed ROS as green dots spread in the cytoplasm and partially overlapping with red fluorescence of mitochondria
(Figure 8A). The measurement of the fluorescent signals co-localization revealed that approximately $40-50 \%$ of ROS localized at mitochondrial level. The increase of ROS at mitochondrial level might be related to damages at the organelles' membrane. The mitochondrial damage was then analyzed by flow cytometry. Cells treated with PM for $24 \mathrm{~h}$ presented a statistically significant reduction of mitochondrial fluorescence signal (MitoTracker) compared to controls (Figure $8 \mathrm{~B}$ ). In contrast, carbonaceous particles $(\mathrm{CB})$ were ineffective.

To better clarify any possible role of mitochondria in ROS formation, the specific mitochondrial superoxide indicator MitoSOX was used. The results showed that mitochondrial superoxide was not significantly increased after $2 \mathrm{~h}$ of $\mathrm{PM}$ exposure (Figure $8 \mathrm{C} 1$ and $\mathrm{C} 2$ ). This 


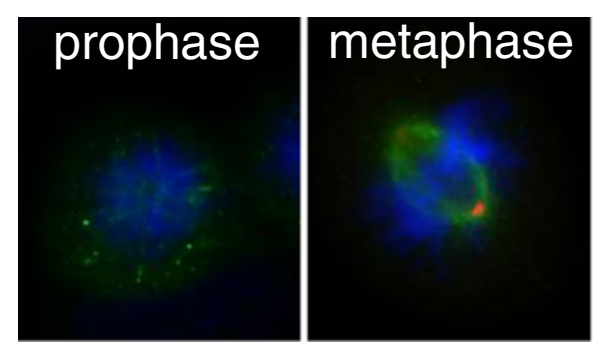

pre-anaphase

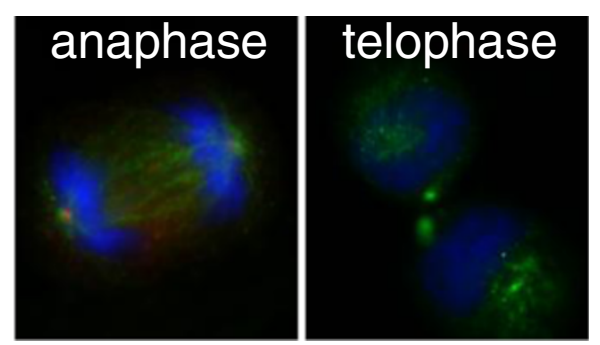

post-anaphase

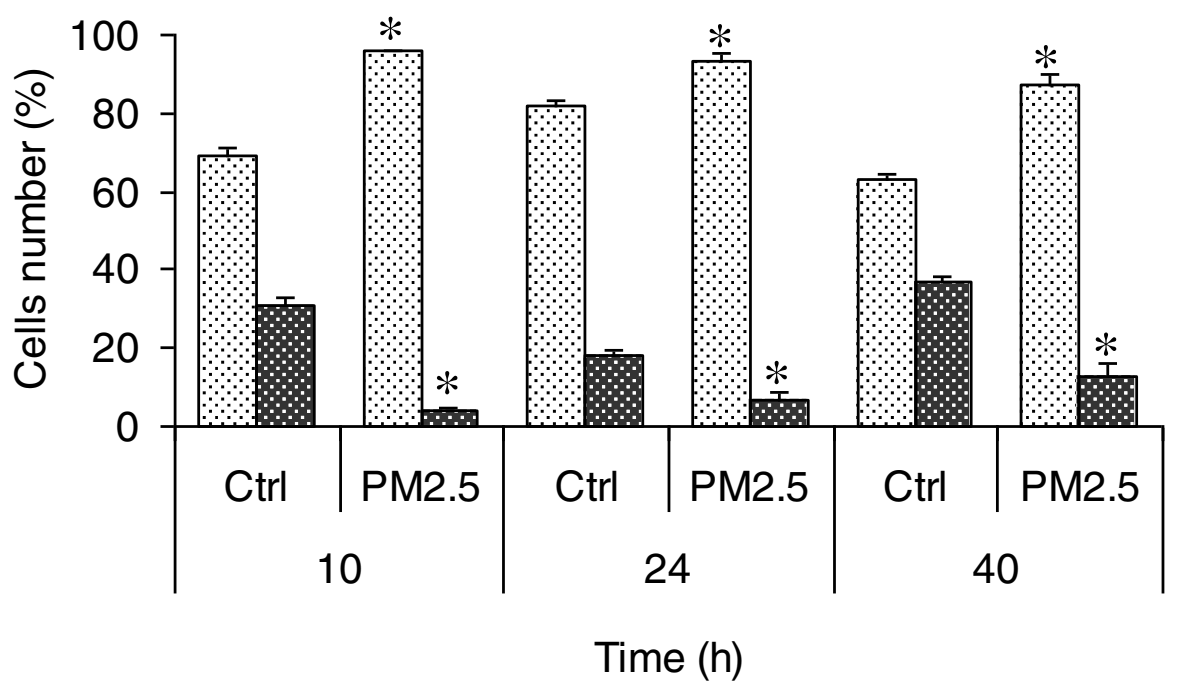

Figure 3 Analysis of the mitotic phases. BEAS-2B cells were exposed for 10, 24 and $40 \mathrm{~h}$ to $7.5 \mathrm{\mu g} / \mathrm{cm}^{2}$ of winter PM2.5, stained for DNA (blue) and $\beta$-tubulin (green) and scored as pre-anaphasic and post-anaphasic cells. The results are representative of 3 independent experiments; in each experiment 200 cells were scored. *Statistically significant difference from untreated cells (control), P $<0.05$.

suggests that ROS formation was not directly related to mitochondrial alteration at this time point, and the colocalization signal was due to other mechanisms occurring at/or close to the mitochondria. However, a significant increase of MitoSOX signal was measured at $24 \mathrm{~h}$ (Figure $8 \mathrm{C} 1$ and $\mathrm{C} 2$ ), when mitochondrial damage was present (Figure $8 \mathrm{~B} 1$ and $\mathrm{B} 2$ ).

Since cell cycle arrest is often related to DNA damage, whole-PM2.5 and its organic extract were tested for their DNA-damaging potential. Figure 9A illustrates PMinduced DNA damage after $3 \mathrm{~h}$ of exposure, analysed by the SCGE-assay under alkaline conditions; a significant increase in tail intensity was present. The AhR/CYP-inhibitor $\alpha$-naphthoflavone ( $\alpha-\mathrm{NF})$, as well as the nucleophilic antioxidants $\mathrm{N}$-acetylcysteine (NAC) and thiourea (Thio), significantly reduced this effect, suggesting that DNA damage might be related to the formation of reactive metabolites and ROS via the P450 system. Preliminary data with the enzyme Formamidopyrimidine DNA-glycosylase (Fpg), which converts 8-oxodG to DNA-alkali-labile sites, did not result in significant increases in DNA damage in the PM-treated samples when compared to controls (data not shown). This result is in accordance with previous findings obtained with higher PM doses after $24 \mathrm{~h}$ of exposure [21]. ${ }^{32} \mathrm{P}$-postlabelling analysis showed that bulky DNA adduct formation increased 1.7-fold after $24 \mathrm{~h}$ exposure to PM organic extract relative to controls (Figure 9B); representative autoradiograms showing DNA adduct profiles are provided as supplementary material (Additional file 1). No significant increase was observed after $3 \mathrm{~h}$ of exposure. Benzo[a]pyrene $(\mathrm{BaP})$ treatment, used as positive control, resulted in significant DNA adduct formation after 3 and $24 \mathrm{~h}$, confirming that BEAS-2B cells are metabolically competent to mediate CYP-catalysed PAH bioactivation.

DNA double-strand breaks (DSBs), assessed by measuring the levels of $\gamma \mathrm{H} 2 \mathrm{AX}$, were increased in cells exposed for $3 \mathrm{~h}$ to PM2.5 and organic extract (Figure 9C); 8-oxodG was increased by winter PM2.5, while organic extract and $\mathrm{BaP}$ were ineffective (Figure 9D).

$\alpha-\mathrm{NF}$ and NAC completely abolished the G2/M-accumulation visible after exposure to PM or its organic fraction (Figure 10), confirming that ROS and P450-formed 

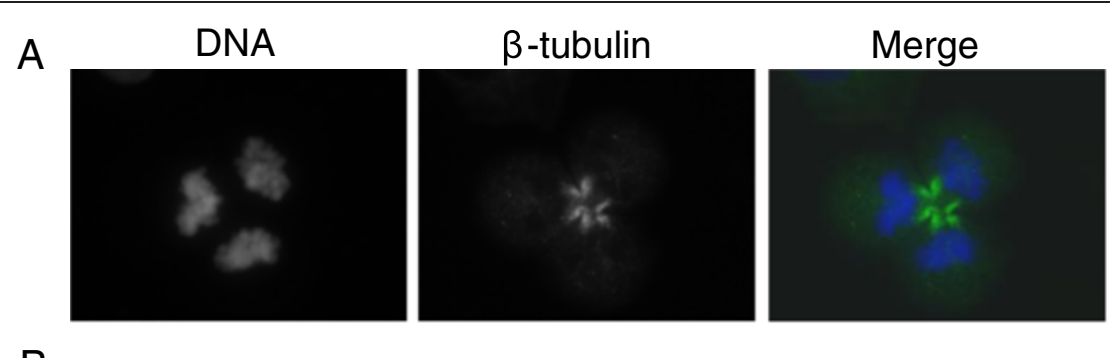

B
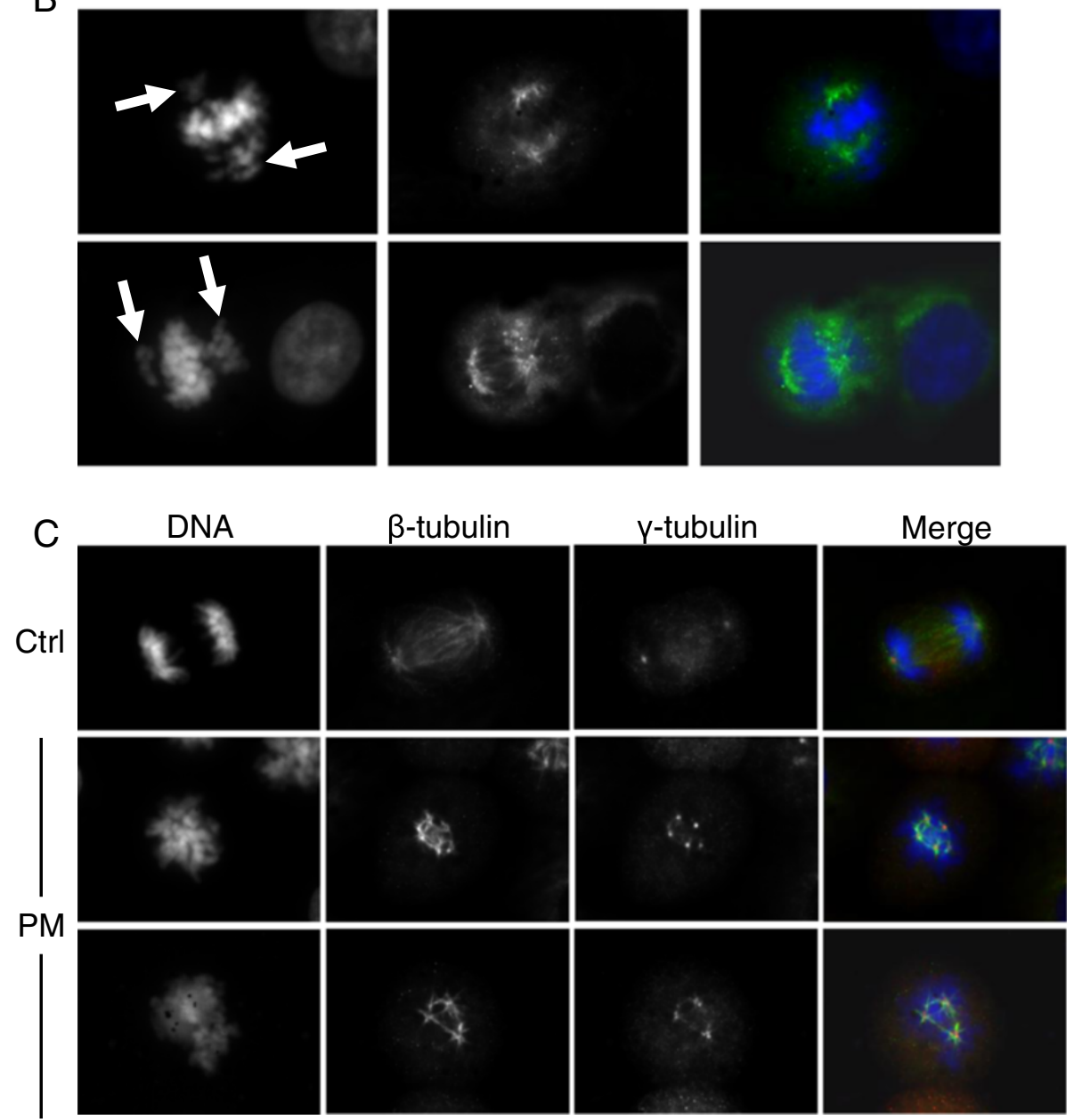

Figure 4 Mitotic spindle analysis. BEAS-2B cells were exposed for $10 \mathrm{~h}$ to $7.5 \mu \mathrm{g} / \mathrm{cm}^{2}$ of winter PM2.5: $\beta$-tubulin (green) and DNA (blue) staining evidenced tripolar mitotic cell (A, telophase; $8 \%$ of mitotic cells in treated samples vs. $2 \%$ in controls; statistically significant difference, $\mathrm{P}<0.05)$; and bipolar incomplete spindle with groups of lagging chromosomes (B, arrows; $10 \%$ of mitotic cells in treated samples vs. $1 \%$ in controls; statistically significant difference, $\mathrm{P}<0.05$ ); $\gamma$-tubulin staining (red) showed centrosomes amplification $(\mathbf{C}, 6.7 \%$ of mitotic cells in treated samples vs. $2.7 \%$ in controls; statistically significant difference, $P<0.05$ ). The results are representative of 3 independent experiments; in each experiment 300 cells were scored.

reactive metabolites of the organic fraction are responsible for the cell cycle delay.

\section{Discussion}

In the present study we showed that $7.5 \mu \mathrm{g} / \mathrm{cm}^{2}$ of a well-characterized urban fine PM (Milan winter PM2.5) caused alterations in different phases of the cell cycle, resulting in apoptotic cell death, tetraploid G1 cells (binucleated) and cells with MN.

PM exposure has previously been reported to result in an accumulation of cells at various cell cycle phases $[20,22,23]$. Besides PM characteristics and dose, time of analysis and the specific cell line used may also influence the results obtained [23,33]. We have previously reported that $25 \mu \mathrm{g} / \mathrm{cm}^{2}$ of Milan winter PM2.5 induced 


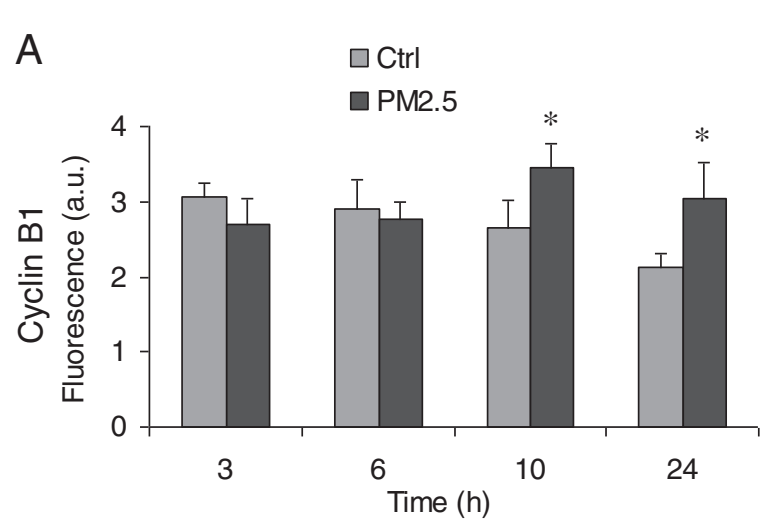

B
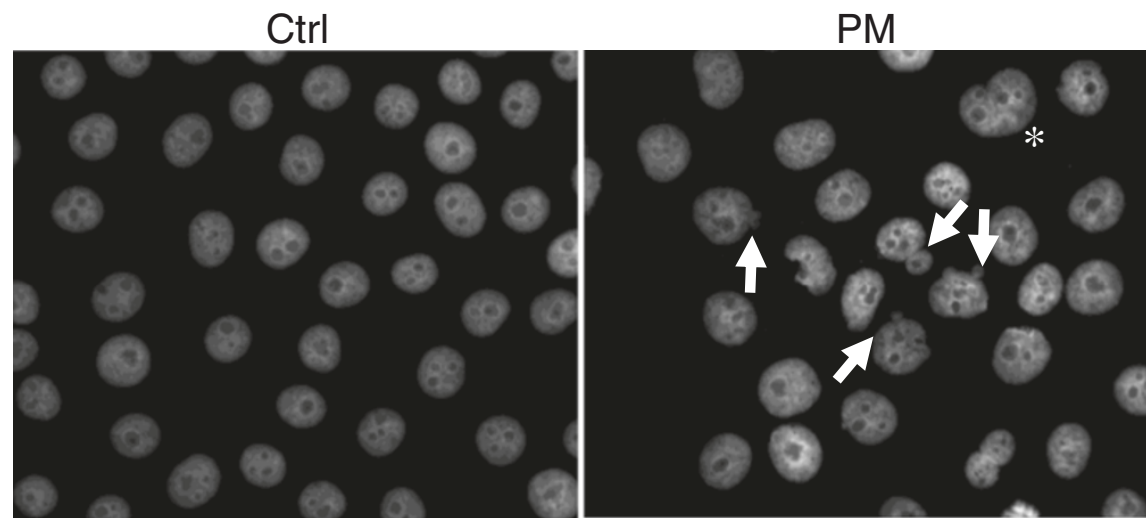

Figure 5 Mitotic process analysis. (A) Cyclin B1 expression was measured by flow cytometry in BEAS-2B cells exposed for 3, 6, 10 and $24 \mathrm{~h}$ to $7.5 \mathrm{\mu g} / \mathrm{cm}^{2}$ of winter PM2.5. The results are reported as fluorescence arbitrary units (mean \pm SEM of 3 independent experiments). *Statistically significant difference from untreated cells (control), $P<0.05$. (B) Nuclear morphology of BEAS-2B cells exposed for $24 \mathrm{~h}$ to $7.5 \mu \mathrm{g} / \mathrm{cm}^{2}$ of winter PM2.5: fluorescence microscopy illustrating micronucleated (arrows, $18.8 \%$ in treated samples vs. $3.2 \%$ in controls; statistically significant difference, $\mathrm{P}<0.05)$ and binucleated (asterisk) cells. The results are representative of 3 independent experiments; in each experiment 300 cells were scored.

mitotic arrest in BEAS-2B cells after $20 \mathrm{~h}$ of exposure which later resulted in mitotic cell death [21]. Here we investigated the in vitro effects of a PM-dose which is among the lowest reported in literature to give biological effects, in an effort to approach environmental human exposure levels. Using this dose, the various phases of the cell cycle were differently affected and little mitotic apoptosis was observed. As results on cell cycle distribution are highly dependent on the time of the analysis, the cell cycle progression has been followed at different time points. A significant increase of cells in G2/M phases already occurred after $3 \mathrm{~h}$ of exposure. The G2/ $\mathrm{M}$ increase was sustained up to $24 \mathrm{~h}$, but it consisted of alterations at three different phases of the cell cycle progression. The combined use of flow cytometry and fluorescence microscopy revealed an early (after $3 \mathrm{~h}$ ) delay in the G2 phase. This was followed by an increased number of cells in mitosis (after $10 \mathrm{~h}$ ). Finally, cytokinesis was affected, because an increased number of non-mitotic tetraploid (4 N) G1 cells was seen after $24 \mathrm{~h}$. The increase of cells in the subG1 region suggests that part of the cells affected by PM treatment die through apoptosis at $40 \mathrm{~h}$.

The cell cycle delay has often been linked to DNA damage and the DNA damage response [20,23,34]. The G2/M transition checkpoint is a non-genomic and rapid-response system activated by DNA damage response [24]. The rapid G2 block is primarily induced in a transient mode and requires p53 transcriptional activity to ultimately produce a sustained block [24,27]. Transient or sustained by p53, the checkpoint protein kinase Chk2 is a pivotal messenger of this system. In the present study we observed a significant increase in the level of the active phosphorylated form of Chk2 (pChk2) in cells treated with winter PM2.5 for $3 \mathrm{~h}$, which is in line with the accumulation in G2 phase reported. The levels of pChk2 decrease to control values after $10 \mathrm{~h}$ of exposure, suggesting that the cells have overcome the G2 arrest and have entered mitosis. Accordingly, the levels of p53 and pp53 appear not to be affected by PM treatment at 3 and $10 \mathrm{~h}$; these data confirm that cells exposed to PM were arrested transiently in $\mathrm{G} 2$ by a p53- 


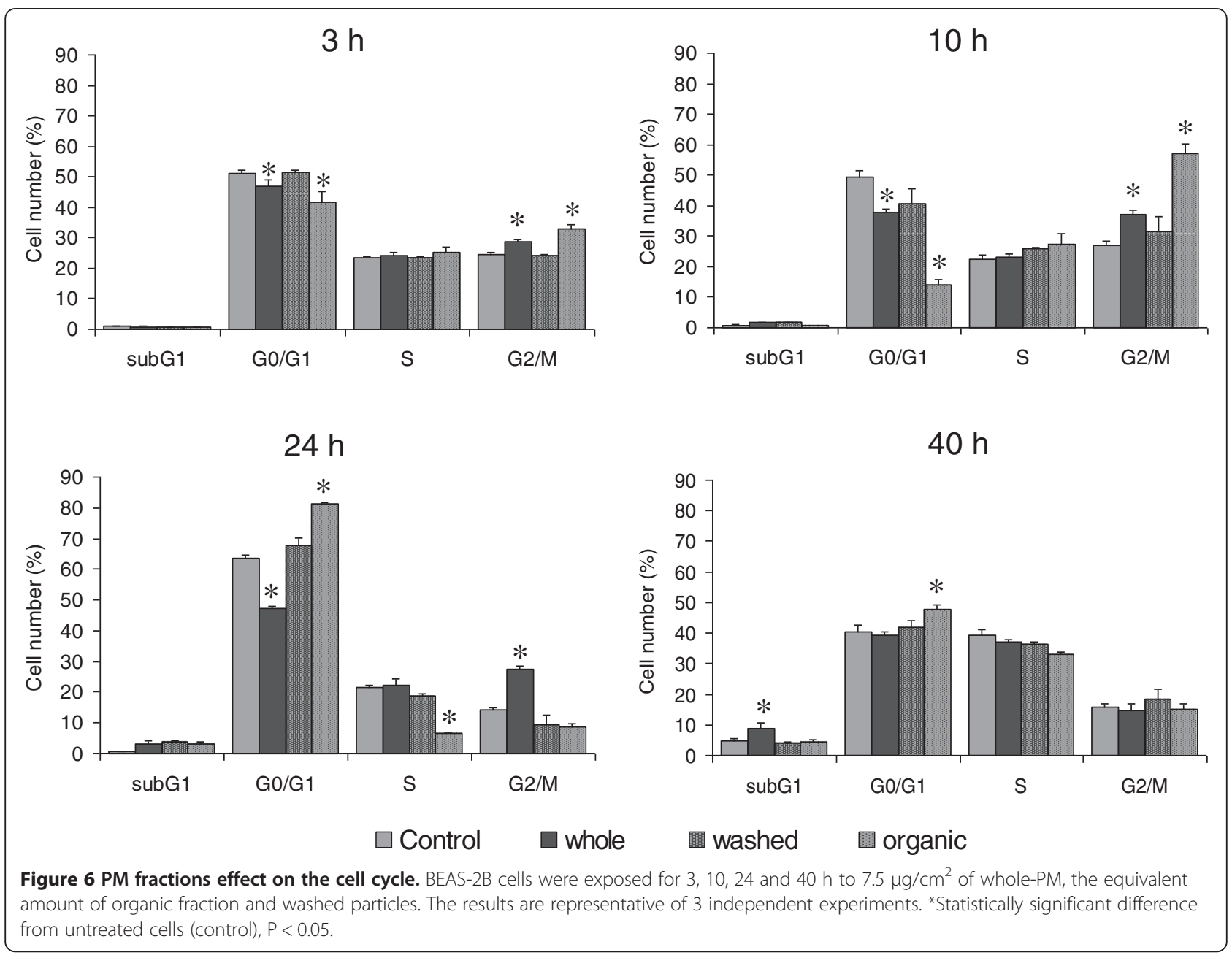

independent pathway at $3 \mathrm{~h}$ of exposure and then escape from $\mathrm{G} 2$ into mitosis after $10 \mathrm{~h}$.

When studying DNA damage and DNA damage responses in vitro it is essential to avoid cell lines with TP53 mutations, as the loss of p53 activity is linked to defects in cell cycle control and apoptosis after DNA damage [35]. Here we used BEAS-2B cells, which are reported to have normal p53 activity, and for this reason have been widely used to study cell cycle alterations [36] and mechanisms involved in PM-induced toxicity $[37,38]$. Nevertheless, it should be noted that this cell line is SV 40-transformed, thus these effects should be further explored in primary human lung epithelial cells and/or in vivo.

The alterations of the cell cycle may not only depend on DNA damage but also on damages to other macromolecules, as well as on changes in protein phosphorylation and ion concentrations [24]. As shown in the present study, the various cell cycle steps affected in PM2.5-exposed cells suggest that several types of initial damage might be involved. The mitotic arrest was characterized by disequilibrium in the different mitotic phases (higher incidence of pro- and metaphase cells versus ana- and telophase ones) suggesting possible structural dysfunctions of microtubules (MT) and of mitotic spindle assembly. Furthermore, mitotic cells presented various aberrations of the mitotic apparatus, including tripolar, multipolar and incomplete spindles. Moreover, $\gamma$-tubulin staining showed centrosomes amplification. Similar spindle aberrations have been reported in Chinese hamster fibroblasts after exposure to PM10 [39] and in our previous study, where preliminary results showed the presence of tripolar cells [21]. These findings indicate that PM may act as spindle poison, directly perturbing microtubules dynamics, and suggest the activation of the spindle assembly checkpoint (SAC) as a mechanism for the M/A delay. Indeed, centrosomes amplification and increased number of spindle poles are known to cause a delay in the anaphase onset through SAC activation [40]. Further, SAC can also be activated by the presence of incomplete bipolar spindles with lagging chromosomes, similar to the ones we found. Pole- 


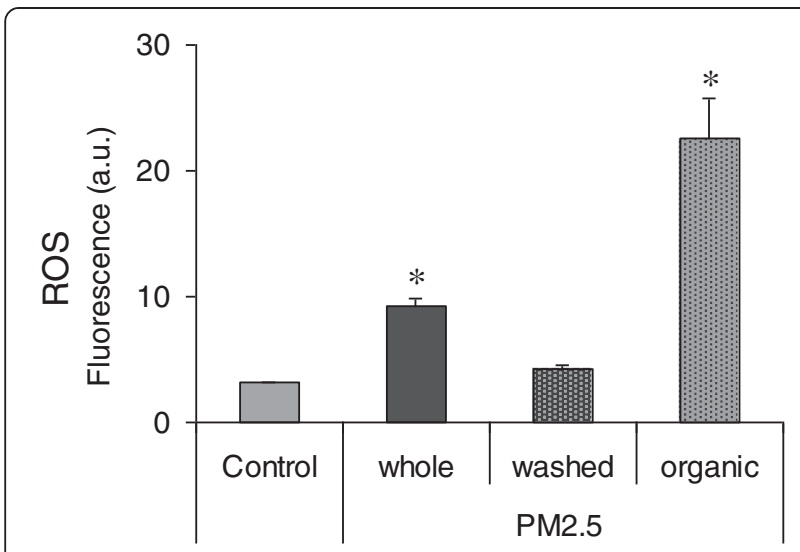

Figure 7 ROS formation in BEAS-2B cells. Cells were exposed for $2 \mathrm{~h}$ to $7.5 \mathrm{\mu g} / \mathrm{cm}^{2}$ of winter PM2.5 and to the equivalent amount of organic fraction and of washed particles. The results are reported as fluorescence arbitrary units (mean \pm SEM of 3 independent experiments). * Statistically significant difference from untreated cells (control), $\mathrm{P}<0.05$

associated chromosomes are a regular transient feature of astral spindle assembly, when an initial monotelic attachment brings the chromosomes towards the centrosomes. Under normal conditions this feature should be rapidly corrected by an Aurora-B kinase-based mechanism [24]. The presence of a high percentage of cells with pole-associated chromosomes (10\% in PM-treated samples) suggests a delay in the rearrangement of this attachment.

After exposure to PM for $24 \mathrm{~h}$ the number of cells was slightly reduced relative to controls, without significant levels of mitotic-apoptosis. However, an increased number of non-mitotic cells with double amount of DNA (4 N), large or double nuclei, and cells with micronuclei $(\mathrm{MN})$ were present, suggesting that cells, when arrested in mitosis, did not always complete cytokinesis. It is well known that cells arrested by SAC at the M/A transition point can exit mitosis without proper segregation of chromosomes and cytokinesis, if the damages are not properly corrected within a certain period of time. This process (called mitotic slippage) gives rise to cells with large or double nuclei (4 N, G1) and with multiple micronuclei [29], as we found. In agreement with the literature [30], cells with amplified centrosomes, forming tripolar mitotic spindles, seemed to go through karyokinesis, as tripolar cells in anaphase and telophase were frequently observed. These cells might contribute to the increased subG1 peak reported after $40 \mathrm{~h}$ of exposure, which can be only partly explained by the increase of apoptosis observed at this time point. In contrast, cells with more than three poles were never found in anaphase and telophase, suggesting that they failed the cytokinesis, resulting in binucleated or micronucleated cells.
Cells exposed for $24 \mathrm{~h}$ to PM also presented high levels of cyclin B protein. This further supports the hypothesis of SAC activation, as SAC inhibits the anaphase-promoting complex (APC)-dependent degradation of cyclin B. Moreover it has been demonstrated that cyclin B degradation not only is required for the transition to anaphase, but also for the onset of cytokinesis in Drosophila [41]. Interestingly, Burns et al. [42] found high levels of cyclin B1 in $4 \mathrm{~N}$ cells treated with nocodazole and paclitaxel. On the other hand, Brito and Rieder [43] reported that cyclin B degradation is required for mitotic slippage; thus the role of cyclin B in this event is still a matter of debate.

The results obtained from the various PM fractions (organic fraction versus inorganic and carbonaceous particles) showed that the organic components of Milan winter PM2.5 are very important for the effects on the cell cycle, as particles deprived of these compounds were ineffective. This observation is in line with previous results showing that Milan summer PM2.5, with low quantity of PAHs, had no effect on the mitotic progression [44]. Accordingly, other data in the literature [45-47] describe the role of PM organic compounds in inducing toxicity. In most of these studies $[48,49]$, the high PAHs content has been associated with high genotoxicity, oxidative stress, and mitochondrial and cytoskeletal dysfunctions. Möller and colleagues [50] reported effects on phagocytosis, phagosome transport mechanisms and cytoskeletal integrity. PAHs-rich PM0.2, produced by combustion of solid fuels, induced G2/M arrest in macrophages [23], while organic extracts from PM2.5 and PM10 arrested the cell cycle of different human cell lines in G0/G1 $[22,51]$. Several PAHs are able to alter the cell cycle in various ways; dibenzo[a,l]pyrene induces $\mathrm{G} 2 / \mathrm{M}$ arrest in human mammary carcinoma MCF-7 cells [52], while it delays HEL fibroblasts in the $S$ phase [53]. Similarly, exposure to $\mathrm{BaP}$ leads to $\mathrm{S}$ phase accumulation in human hepatocarcinoma HepG2 and MCF-7 cells [54]. Moreover, recent results have shown that the cell cycle status can impact on BaP metabolism and DNA damage [55]. Thus, how PAHs adsorbed on PM may affect the cell cycle depends on the specific compounds present and the cells' metabolic capacity. The compounds' bioavailability is also of importance, which was demonstrated in the present study by the higher potential of the PM organic fraction in comparison with the whole-PM to induce ROS formation. On the other hand, the whole-PM longer sustained the cellular arrest in G2/M when compared to the organic fraction, and induced oxidative DNA damage. Thus, the localization of PAHs on the particles is probably of importance for some of the PM-induced effects. However, a role for other components cannot 


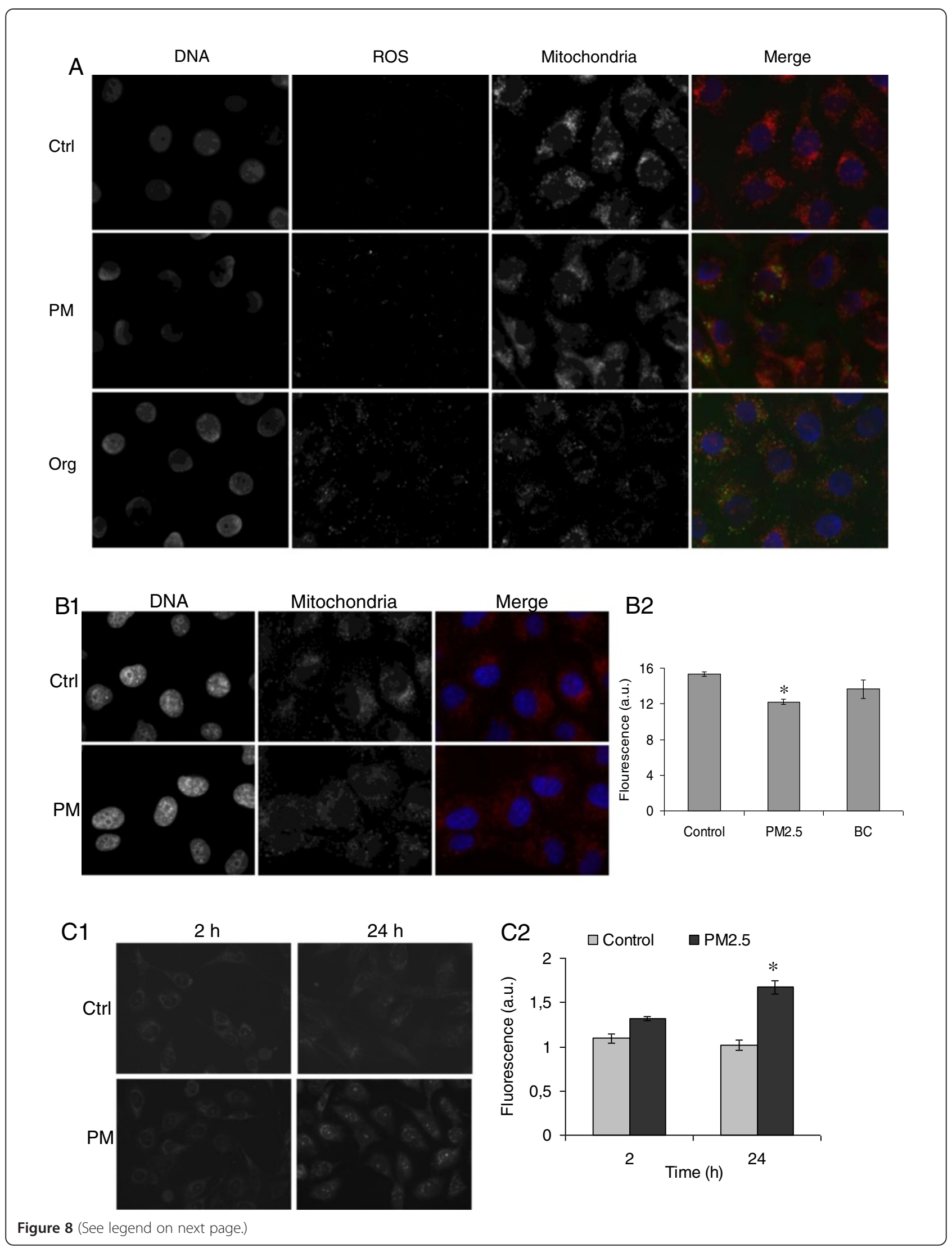


(See figure on previous page.)

Figure 8 Analysis of mitochondrial damage. (A) ROS and mitochondria co-localization was assessed by fluorescence microscopy. BEAS-2B cells, exposed for $2 \mathrm{~h}$ to $7.5 \mathrm{\mu g} / \mathrm{cm}^{2}$ of winter PM2.5 and to its organic fraction, were stained for DNA, ROS and mitochondria. Co-localization signal of ROS and mitochondria was measured by Axiovision Rel 4.8 software as reported in materials and methods. (B) Mitochondrial damage in BEAS-2B cells exposed for $24 \mathrm{~h}$ to $7.5 \mu \mathrm{g} / \mathrm{cm}^{2}$ of winter PM2.5 was assessed by fluorescence microscopy (B1) and flow cytometry (B2). Flow cytometry results are reported as fluorescence arbitrary units (mean \pm SEM of 3 independent experiments). Carbon black (CB) was used as reference control for carbonaceous particles effects. (C) Mitochondrial superoxide formation in BEAS-2B cells exposed for 2 and $24 \mathrm{~h}$ to $7.5 \mu \mathrm{g} / \mathrm{cm}^{2}$ of winter PM2.5 was assessed by fluorescence microscopy (C1) and flow cytometry (C2). Flow cytometer results are reported as fluorescence arbitrary units (mean \pm SEM of 3 independent experiments). Hydrogen peroxide $(1 \mathrm{mM}$ ) was used as positive control and reported $3.4 \pm 0.11$ and $12.6 \pm 0.09$ as fluorescence arbitrary units at 2 and $24 \mathrm{~h}$, respectively. ${ }^{*}$ Statistically significant difference from untreated cells (control), $\mathrm{P}<0.05$.

be excluded. These could be some metals in the water soluble PM fractions, which have been shown to alter mitosis progression $[56,57]$.

The organic fraction seemed to be responsible for the increase of ROS observed at $2 \mathrm{~h}$ of exposure. ROS formation after PM exposure is associated with significant cell effects such as mitochondrial damage, increased production of cytokines and chemokines, as well as DNA damage $[2,58,59]$. Moreover, high levels of oxidants determine perturbation of the mitochondrial permeability and a disruption of electron transfer chain resulting in cellular apoptosis or necrosis [58]. Mitochondria have been indicated as the main source of ROS generation in rat alveolar type II and human lung adenocarcinoma A549 cells exposed to a high dose of PM2.5 $\left(50 \mu \mathrm{g} / \mathrm{cm}^{2}\right)$ [32]. However in this study, after exposure to $7.5 \mu \mathrm{g} / \mathrm{cm}^{2}$, only $40-50 \%$ of total ROS were localized at the mitochondria, while the rest of ROS were located in the cytoplasm. Moreover, the absence of mitochondrial superoxide formation indicated that mitochondria

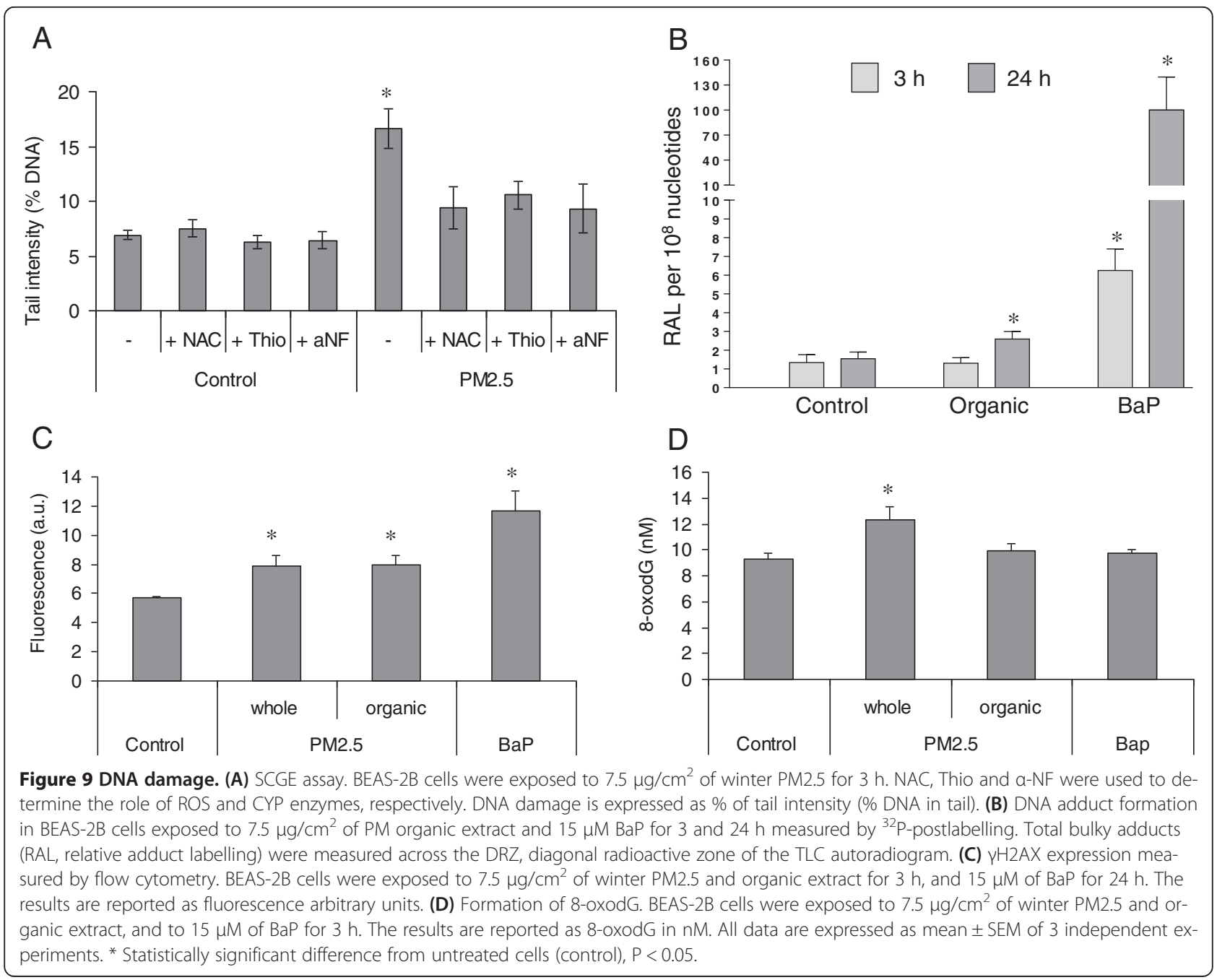




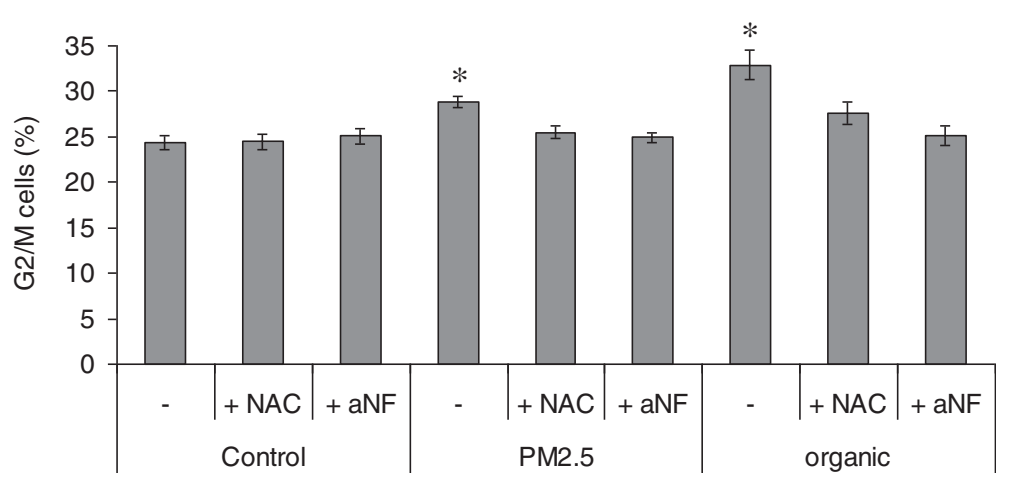

Figure 10 G2/M cells percentage. Cells percentage was assessed by cell cycle analysis of BEAS-2B cells exposed for $3 \mathrm{~h} \mathrm{to} 7.5 \mu \mathrm{g} / \mathrm{cm}^{2}$ of wholePM and organic fraction. NAC and a-NF were used to determine the role of ROS and CYP enzymes, respectively. ${ }^{*}$ Statistically significant difference from control, $P<0.05$. The results are representative of 3 independent experiments.

are not significantly involved in ROS production at $2 \mathrm{~h}$. Considering these results, it is likely that the organic fraction is responsible for PM-induced ROS through P450-mediated metabolic activation of various PAHs and oxo-PAHs. The co-localization of ROS signal and mitochondria might be due to CYP enzymes, which have been recently reported to have also mitochondrial localization [60]. Still, the contribution of other pathways (such as AKR or NADPH oxidase) cannot be excluded [61] and should be further investigated.

As mitochondrial superoxide formation was found at $24 \mathrm{~h}$, this effect is likely secondary to ROS formation, and may be caused by the observed mitochondrial damage.

The results in this study show that PM was able to induce DNA damage as determined by comet assay, measuring strand breaks and alkali-labile sites. The AhRresponse has previously been found to be of major importance in explaining the toxicity of various PM $[21,62,63]$ and of its organic fraction [64]. In accordance with this, antioxidants NAC and Thio, and the AhR/ CYP enzymes inhibitor $\alpha$-NF reduced the PM-induced DNA damage, as well as the G2 increase occurring at $3 \mathrm{~h}$ of exposure. These findings suggest that these effects were related to ROS and/or other reactive metabolites formed by AhR/CYP enzymes.

ROS-induced DNA damage includes various oxidative DNA base modifications as well as single and double strand breaks (SSBs and DSBs) [65,66], while the reactive PAHs intermediates might also induce bulky DNA adducts $[62,67]$. A further characterization of PM-induced DNA damage by ${ }^{32} \mathrm{P}$-postlabelling showed that the PM organic fraction induced higher bulky DNA adduct levels after $24 \mathrm{~h}$ of exposure, while no difference was seen after $3 \mathrm{~h}$. Similar results following PM exposure have been reported by others $[15,62]$. PAHs which form DNA adducts often require a two-steps activation [67], which might undergo competitive inhibition by non-genotoxic PAHs present in the PM complex mixture [68]. Thus, the primary DNA damage detected by the comet assay might be those induced by organics and PAHs needing only one-step activation, such as nitro- and oxo-PAH.

Although the comet assay with Fpg was negative, the levels of 8-oxodG and $\gamma \mathrm{H} 2 \mathrm{AX}$ measured by immunostaining increased after $3 \mathrm{~h}$ of PM exposure, suggesting the presence of oxidative DNA damage and DSBs. A similar lack of effect of comet assay with Fpg, despite positive immunostaining, have previously been reported [21] and is probably due to an artefact; various micro and nanoparticles have been reported to interact with Fpg, decreasing the sensitivity of the assay [69], and PM may have similar effects.

Interestingly, 8-oxodG was increased by whole-PM but not by its organic extract, suggesting a more direct interaction of some PM component (including both metals and various PAHs) with the DNA in the nucleus [70-72]. It is known that 8-oxodG is induced by singlet oxygen and hydroxyl radical which, due to their high reactivity, will only react with DNA when generated in direct proximity [65]. Thus, our results suggest that ROS formed in the cytosol when exposed to the organic fraction will not interact with the cellular DNA. Previous data in our laboratory indicated that PM may be in close contact with the chromosomes [21], but the current data is not conclusive and this potential nuclear localization of PM would require further investigations.

In conclusion, the dose used in the present study is among the lowest reported to have biological effects in vitro [73]. Our study shows that this low dose of winter PM2.5 induces an early G2 arrest followed by an arrest in M/A with a subsequent inhibition of cytokinesis and an increased formation of cells with double nuclei and MN. These effects are associated with a rapid DNA damage response and the formation of mitotic spindle aberrations. The early DNA damage and G2/M accumulation have been related to the formation of reactive 
electrophilic/radical metabolites via a P450-depending reaction. However, PM2.5 apparently also has spindle poison properties which contribute to the induction of the M/A arrest. The characterization of the process leading to double nuclei and $\mathrm{MN}$ in PM-exposed cells is of great importance, giving a possible explanation for PMinduced chromosomal aberrations. Such events could be central when explaining the increased lung cancer incidence associated with PM2.5 and deserve further investigations.

\section{Materials and methods}

\section{PM collection and preparation}

PM samples were collected during winter 2009/2010 at Torre Sarca, a site of Milan urban background for atmospheric pollution. Milan winter PM2.5 ambient concentration is $50 \mu \mathrm{g} / \mathrm{m}^{3} \pm 29$ (mean $\pm \mathrm{SD}$ ). Samplings were performed on Teflon filters by a low volume gravimetric sampler (EU system, FAI Instruments, Rome, Italy); on average the particles mass was $1.5 \mathrm{mg}$ per filter after $24 \mathrm{~h}$ of sampling. Filters were replaced every $24 \mathrm{~h}$ and then they all were stored in one pool representative of the winter PM. Particles were extracted as previously described [74]. Briefly, filters were detached from plastic holders and, after immersion in $2 \mathrm{ml}$ of sterile water, underwent four cycles of $20 \mathrm{~min}$ each in an ultrasound bath (SONICA, Soltec). The extraction water was replaced every sonication cycle, and the volumes obtained from the four cycles were put together to obtain a homogeneous sample. Particle suspensions were dried in a desiccator $(72 \mathrm{~h})$, weighed and stored at $-20^{\circ} \mathrm{C}$, and the resulting pellets were re-suspended in sterile water $(2 \mu \mathrm{g} / \mu \mathrm{l})$ just prior to use.

This standardized procedure for ambient particulates does not modify the natural state of particles aggregates. The extraction efficiency, i.e. PM mass extracted compared to the PM total mass on filters, has been found to be approximately $75 \%$ regardless of the dimension, origin or chemical composition of the particles (similar efficiency for PM1, PM2.5 and PM10, sampled in summer or winter). These observations assure the similarity between the extracted particles and the original ones.

As an additional check of the method, solutions have been produced in the same way from unloaded teflon filters and used to treat the cells; various toxicological tests were performed (viability, release of inflammatory proteins, cell cycle alterations and ROS formation) and no effects have been observed in comparison to untreated control cells.

PM2.5 organic extract was obtained by re-suspending particle pellets in acetonitrile (Sigma-Aldrich), according to the procedure used for the chemical characterization of PM. The extraction efficiency has been evaluated and recoveries were over $65 \%$ for all the analyzed PAHs [75].
After centrifugation (15 $\mathrm{min}, 12000 \mathrm{rpm}, 4^{\circ} \mathrm{C}$ ), supernatant and pellet were separated and dried in a desiccator. The organic fraction, obtained from the supernatant, was dissolved in DMSO $(10 \mu \mathrm{g} / \mu \mathrm{l}$ of original pellet weight), while washed particles were re-suspended in sterile water $(2 \mu \mathrm{g} / \mu \mathrm{l}$ of original pellet weight).

The chemical and morphological characterization of the PM used has been previously reported [74-76]. Briefly, suspensions obtained from atmospheric samples were analysed by transmission electron microscopy. The winter PM2.5 appeared as aggregates of small, roundshaped particles, and the particle size distribution confirmed that few particles exceeded $1 \mu \mathrm{m}$ in diameter [74]. Analyses by IC, TOT, ICP-MS and GC-MS evidenced that particles were mainly composed of watersoluble inorganic ions $\left(\mathrm{NH}_{4}^{+}, \mathrm{NO}_{3}^{-}\right.$and $\left.\mathrm{SO}_{4}^{2-}\right)$, organic and elemental carbon, and elements. A high PAH concentration $(0.06 \%$ of the total PM mass) was measured, and the most abundant elements were Fe, $\mathrm{Zn}$ and $\mathrm{Al}$.

\section{Cell culture and exposure}

The human bronchial epithelial cell line BEAS-2B (SV40 hybrid, Ad12SV40, transformed) was purchased from the European Collection of Cell Cultures (ECACC, Salisbury, UK). Cells were maintained in LHC-9 medium at $37^{\circ} \mathrm{C}$ with $5 \%$ of $\mathrm{CO}_{2}$, split every three days and the medium was changed the day after. For experiments, cells were seeded at a concentration of 80,000 cells/well in 6-well plates, or $1 \times 10^{6}$ cells in Petri dishes $(\varnothing=10 \mathrm{~cm})$, and after two days treated with $7.5 \mu \mathrm{g} / \mathrm{cm}^{2}$ of winter PM2.5 or the equivalent amount of organic extract/washed particles. The exposure dose used was selected on the basis of a previous study, choosing a low effective dose [21]. The cellular responses were examined after 1, 3, 6, 10, 24 and $40 \mathrm{~h}$ of exposure and the results compared to those of untreated cells (control). Cells were pre-incubated for $1 \mathrm{~h}$ with antioxidants, NAC $(10 \mathrm{mM})$ or Thio $(100 \mu \mathrm{M})$, or the CYP/AhR inhibitor $\alpha-\mathrm{NF}(10 \mu \mathrm{M})$, before exposure to particles. CB $\left(7.5 \mu \mathrm{g} / \mathrm{cm}^{2}\right.$; Sigma-Aldrich, Italy) was used as a reference carbonaceous material. Hydrogen peroxide $\left(\mathrm{H}_{2} \mathrm{O}_{2}, 1 \mathrm{mM}\right.$ final concentration), topoisomerase II inhibitor etoposide (Etop, $250 \mathrm{nM}$ ) and benzo[a]pyrene (BaP, $15 \mu \mathrm{M})$ were used as positive controls for mitochondrial superoxide formation, p53/pp53 activation and DNA adduct formation, respectively.

\section{Flow cytometry}

\section{Cell cycle analysis}

The cell cycle after exposure to PM, PM-extracts, or washed PM was analyzed at different time points by flow cytometry. Briefly, cells were harvested, fixed in 70\% ethanol at $-20^{\circ} \mathrm{C}$ and stored until analysis. After centrifugation, cells were resuspended in PBS with $20 \mu \mathrm{g} / \mathrm{ml}$ RNase DNase-free (Sigma-Aldrich, Italy) and incubated 
at $37^{\circ} \mathrm{C}$ for $30 \mathrm{~min}$. Propidium iodide (PI) was added and fluorescence was measured by the flow cytometer EPICS XL-MCL (Beckman-Coulter) using a $575 \mathrm{~nm}$ band pass filter. Data were analyzed using the EXPO32 ADC software (Beckman-Coulter).

\section{Cyclin B1 expression}

Cyclin B1 levels were assessed by flow cytometry. Cells were harvested, fixed with $1 \%$ paraformaldehyde on ice for $15 \mathrm{~min}$, resuspended in cold methanol $90 \%$ and stored overnight at $-80^{\circ} \mathrm{C}$. After centrifugation, cells were washed once in PBS/0.5\% BSA and incubated with primary antibody (Cyclin B1, 1:100 dilution; Cell Signaling) in $\mathrm{PBS} / 0.5 \% \mathrm{BSA} / 0.2 \%$ Triton $\mathrm{X}-100$ overnight at $4^{\circ} \mathrm{C}$. Alexafluor-488 secondary antibody (1:500; Invitrogen) was incubated for $1 \mathrm{~h}$ at room temperature. Finally, cells were washed once in $\mathrm{PBS} / 0.5 \% \mathrm{BSA}$, resuspended in PBS and analyzed by flow cytometry. Fluorescence of 10,000 events was detected using a $525 \mathrm{~nm}$ band pass filter.

\section{ROS formation}

ROS was measured by the fluorescent probe 2'7'-dichlorodihydrofluorescein diacetate (DCFH-DA; Life Science Technologies, Italy). Cells were incubated at $37^{\circ} \mathrm{C}$ with DCFH-DA $(5 \mu \mathrm{M})$ in PBS for $20 \mathrm{~min}$, washed in PBS and treated with PM, organic extract or washed particles for 45 or $120 \mathrm{~min}$, harvested and suspended in PBS. The ROS-linked fluorescence was quantified by flow cytometry using a $525 \mathrm{~nm}$ band pass filter. The autofluorescence of cells, PM and PM organic extract was assessed analysing the signal from negative controls (samples not stained with DCFH-DA). These values were then subtracted from the values to DCFH-DA stained samples.

\section{Mitochondrial signal}

MitoTracker Red CMXRos (Invitrogen) was used to measure mitochondrial integrity since the fluorescence signal of this dye is dependent upon membrane potential. Thus, a reduction of MitoTracker fluorescence is considered an indication of decreased mitochondrial membrane potential. BEAS-2B cells exposed for $24 \mathrm{~h}$ to winter PM2.5 and CB $\left(7.5 \mu \mathrm{g} / \mathrm{cm}^{2}\right)$ were harvested, stained with MitoTracker (30 min, $50 \mathrm{nM}$ ) and fluorescence of 10,000 events was detected using $575 \mathrm{~nm}$ band pass filter on the flow cytometer. $C B$ was used to exclude the possibility that the eventual mitochondrial signal reduction may be due to an interaction of the particles with the probe.

MitoSOX Red mitochondrial superoxide indicator (Invitrogen) was used to investigate the role of mitochondria in ROS formation, since this dye selectively detects the superoxide formation in the mitochondria.
BEAS-2B cells were exposed for 2 and $24 \mathrm{~h}$ to winter PM2.5 $\left(7.5 \mu \mathrm{g} / \mathrm{cm}^{2}\right)$ and $\mathrm{H}_{2} \mathrm{O}_{2}$ (positive control, $1 \mathrm{mM}$ ). At the end of the treatment $2 \mu \mathrm{M}$ MitoSOX Red working solution was freshly prepared in $\mathrm{HBSS} / \mathrm{Ca} / \mathrm{Mg}$ and incubated with the cells for 15 minutes at $37^{\circ} \mathrm{C}$, in the dark. Then, cells were harvested and the fluorescence of 10,000 events was detected using a $575 \mathrm{~nm}$ band pass filter on the flow cytometer.

\section{Fluorescence microscopy Immunocytochemistry}

Cells were stained for $\beta$-tubulin and $\gamma$-tubulin to observe mitotic microtubules (MTs) and centrosomes, respectively. Cells for immunocytochemical detection of proteins were prepared following common fluorescence microscopy techniques. Briefly, cells grown on cover slips were treated with PM as described above, washed in PBS and fixed with 1\% paraformaldehyde for $15 \mathrm{~min}$ on ice. Permeabilization and blocking were performed in PBS/0.5\% BSA/0.2\% Triton X-100 for $15 \mathrm{~min}$ at room temperature. Cells were then immunocytochemically labelled with primary antibodies in PBS/0.5\% BSA/0.2\% Triton X-100 overnight at $4^{\circ} \mathrm{C}(\beta$-tubulin 1:200 dilution; $\gamma$-tubulin 1:1000; Cell Signaling). Appropriate Alexafluor secondary antibodies (1:500 dilution; Invitrogen) were incubated for $1 \mathrm{~h}$ at room temperature and cells' DNA counterstained with DAPI. Slides were observed under a fluorescence microscope (AxioObserver, Zeiss Germany) and digital images were taken.

The percentage of mitotic and apoptotic cells was assessed by fluorescence microscopy in samples exposed to PM for 3, 10 and $24 \mathrm{~h}$. According to nuclear morphology, 500 cells per samples were scored as interphasic (uncondensed chromatin), mitotic (condensed chromosomes) or apoptotic (typical highly condensed and fragmented nuclei) cells. Mitotic cells (200 cells per sample) were analysed to assess the mitotic phase; according to arrangement of chromosomes and mitotic spindle, cells were scored as pre-anaphasic (pro- and metaphase) or post-anaphasic (ana- and telophase) cells. After $10 \mathrm{~h}$, 300 cells per sample were scored to further describe the mitotic process, analysing the presence of tripolar and multipolar mitotic cells, and bipolar cells with incomplete spindles and groups of lagging chromosomes. After $24 \mathrm{~h}$, nuclear morphology of 300 cells per sample was observed to investigate the presence of micronuclei $(\mathrm{MN})$ and double nuclei.

\section{Fluorescence microscopy of living cells}

ROS formation and effects on mitochondria were analysed in living cells using DCFH-DA, MitoTracker and MitoSOX dyes. ROS and mitochondria co-localization was investigated after $2 \mathrm{~h}$ of PM treatment. Cells grown on cover slips were first incubated at $37^{\circ} \mathrm{C}$ with $5 \mu \mathrm{M}$ of 
DCFH-DA in PBS for $20 \mathrm{~min}$, then exposed to PM and finally stained with MitoTracker for $30 \mathrm{~min}$ and counterstained with DAPI. Slides were observed under a fluorescence microscope (AxioObserver, Zeiss), digital images were taken with a final magnification of $630 \times(10 \mathrm{x}$ ocular and $63 \times$ objective lens, immersion oil) and colocalization signal was quantified with Axiovision Rel 4.8 co-localization dedicated software (Zeiss). Images of mitochondria stained with MitoTracker were also taken after $24 \mathrm{~h}$ of treatment with PM, to investigate possible secondary effects. Finally, the formation of mitochondrial superoxide was examined by staining the cells with MitoSOX. Briefly, after 2 and $24 \mathrm{~h}$ of PM treatment, cells grown on cover slips were loaded with $2 \mu \mathrm{M}$ MitoSOX working solution for $15 \mathrm{~min}$ at $37^{\circ} \mathrm{C}$, in the dark. Then, cells were washed in $\mathrm{HBSS} / \mathrm{Ca} / \mathrm{Mg}$ and fixed with 3\% paraformaldehyde for $15 \mathrm{~min}$. Digital images were taken by a fluorescence microscope with a final magnification of $630 \times$ (AxioObserver, Zeiss).

\section{Western blotting}

The expression levels of p53 and Chk2, and of their active phosphorylated forms pp53 and pChk2, were analyzed by Western blotting to assess their involvement in cell cycle regulation. After 3 and $10 \mathrm{~h}$ of exposure to winter PM2.5, cells were collected, washed in PBS and stored overnight at $-80^{\circ} \mathrm{C}$. Cells were lysed in RIPA buffer $(50 \mathrm{mM}$ Tris- $\mathrm{HCl} \mathrm{pH} 8 ; 150 \mathrm{mM} \mathrm{NaCl} ; 1 \% \mathrm{NP}-40$; $0.5 \%$ sodium deoxycholate; $0.1 \%$ SDS), sonicated three times for $30 \mathrm{sec}$ on ice and finally homogenised using a syringe needle. Cell lysates were then separated by SDSPAGE on $10 \%$ gels and transferred to nitrocellulose membranes. Blots were incubated with appropriate antibodies (p53, phospho-p53 Ser15, Chk2, phospho-Chk2 Thr68, Cell Signaling Technology, dilution 1:1000; actin, Sigma Aldrich, dilution 1:2000) overnight at $4^{\circ} \mathrm{C}$. After washes, the membranes were incubated with HRPlinked secondary antibodies (anti-rabbit IgG, Cell Signaling Technology, 1:2000; anti-mouse IgG, Sigma Aldrich, 1:80000) and subsequently incubated with Chemiluminescent Peroxidase Substrate (Sigma Aldrich) for detection. Digital images were taken by a luminescence reader (UVP) and densitometry analysis was performed with dedicated software (Launch VisionWorks LS). Data were normalized to the actin content and expressed as fold increase (FI) over control.

\section{DNA damage}

\section{Single cell gel electrophoresis (SCGE)}

After $1 \mathrm{~h}$ exposure to antioxidants and inhibitors and $3 \mathrm{~h}$ exposure to PM, media were removed and cells trypsinized and resuspended at 1 million cells $/ \mathrm{ml}$ in PBS. Samples were analysed for DNA strand breaks and alkali-labile sites using the comet assay. Cells dissolved in $0.68 \%$ LMP agarose
(Gibco BRL 5517US) in PBS with 10 mM EDTA, pH 7.4, were moulded onto GelBond films attached to plastic frames to facilitate subsequent steps. Films underwent lysis (2.5 M NaCl, $0.1 \mathrm{mM} \mathrm{KCl}, 0.5 \mathrm{mM}$ EDTA, pH 8) overnight at $4^{\circ} \mathrm{C}$, and then were transferred to cold electrophoresis solution (0.3 M NaOH, 0.1 M EDTA, >pH 13.2) for $40 \mathrm{~min}$ at $4^{\circ} \mathrm{C}$ for DNA unwinding. After electrophoresis $(\sim 0.8 \mathrm{~V} /$ $\mathrm{cm}, 30 \mathrm{~min}, \mathrm{pH}$ 13.2) and neutralisation, films were fixed in ethanol and dried. Rehydrated samples were stained with SybrGold $(0.08 \mu \mathrm{l} / \mathrm{ml}$ in TE-buffer $\mathrm{pH} 7.4,20 \mathrm{~min})$ and scored with Perceptives Comet IV software. The level of DNA damage was expressed as tail intensity, i.e. percent fluorescence in the comet tail, relative to the comet total fluorescence.

\section{${ }^{32}$ P-postlabelling}

DNA adducts were measured by the thin-layer chromatography (TLC) ${ }^{32} \mathrm{P}$-postlabelling method using the nuclease P1 digestion enrichment version of the assay [77]. After 3 and $24 \mathrm{~h}$ exposure to PM organic extract and $\mathrm{BaP}(15 \mu \mathrm{M})$, cells were washed in PBS, scraped and stored at $-80^{\circ} \mathrm{C}$. DNA was isolated from cells by a standard phenol extraction method and DNA samples were analysed as described [78,79] with minor modifications. Briefly, DNA $(4 \mu \mathrm{g})$ was digested with micrococcal nuclease (288 mU; Sigma, UK) and spleen phosphodiestase (1.2 mU; MP Biomedicals, UK), enriched and labelled as reported. Solvent conditions for the resolution of ${ }^{32} \mathrm{P}$-labelled adducts on polyethyleniminecellulose TLC (Macherery-Nagel, Germany) were: D1, 1.0 M sodium phosphate, $\mathrm{pH}$ 6.0; D3, $4 \mathrm{M}$ lithium-formate, $7 \mathrm{M}$ urea, pH3.5; D4, $0.8 \mathrm{M}$ lithium chloride, 0.5 Tris, $8.5 \mathrm{M}$ urea, $\mathrm{pH}$ 8.0. After chromatography, TLC sheets were scanned using a Packard Instant Imager (Dowers Grove, IL, USA) and DNA adduct levels (RAL, relative adduct labelling) were calculated from the adduct counts per minute (cpm), the specific activity of $\left[\gamma_{-}{ }^{32} \mathrm{P}\right] \mathrm{ATP}$ (Hartmann-Analytic, Germany) and the amount of DNA (pmol of DNA-P) used. As in prior studies, total DNA adduct levels were measured in the diagonal radioactive zone (DRZ) area of the TLC plates and were considered representative of PAHDNA and other aromatic/hydrophobic adducts resistant to nuclease P1 digestion $[78,79]$. The method provides a summary measure of a complex mixture of adducts present in the postlabelling chromatograms. Results were expressed as DNA adducts $/ 10^{8}$ nucleotides. Each DNA sample was determined by two independent ${ }^{32} \mathrm{P}$-postlabelling analyses. An external BaP-diol-expoxide (BPDE)-DNA standard was employed for identification of adducts in experimental samples.

\section{YH2AX}

In order to further investigate DNA damage, $\gamma \mathrm{H} 2 \mathrm{AX}$ was assayed by flow cytometry as a marker of oxidative DSBs. After $3 \mathrm{~h}$ of exposure to PM, organic extract and 
$\mathrm{BaP}$, cells were harvested, fixed with $1 \%$ paraformaldehyde on ice for $15 \mathrm{~min}$, and stored in cold $90 \%$ methanol at $-80^{\circ} \mathrm{C}$ until analysis. Cells were then washed in PBS/ $0.5 \% \mathrm{BSA}$ and incubated $4 \mathrm{~h}$ with Alexafluor- 488 conjugated $\gamma \mathrm{H} 2 \mathrm{AX}$ antibody (1:100 dilution, Cell Signaling) in $\mathrm{PBS} / 0.5 \% \mathrm{BSA} / 0.2 \%$ Triton X-100 at room temperature. Finally, cells were washed and resuspended in PBS and analysed on the Beckman Coulter EPICS XL-MCL flow cytometer. Fluorescence of 10,000 events was detected using $525 \mathrm{~nm}$ band pass filter.

\section{8-oxodG}

The formation of 8-oxodG was investigated as a marker of oxidative DNA damage and oxidative stress, using an 8oxodG ELISA kit (Trevigen). After $3 \mathrm{~h}$ of exposure to PM, organic extract and $\mathrm{BaP}$, cells were trypsinized, washed with PBS and stored at $-80^{\circ} \mathrm{C}$. DNA was extracted using a commercial kit according to the manufacturers' instructions (Qiagen, Flexigen Kit). DNA samples were supplemented with cations and DNase I in proper quantities and incubated for $1 \mathrm{~h}$ at $37^{\circ} \mathrm{C}$. Alkaline phosphatase was then added, and samples were further incubated for $1 \mathrm{~h}$ at $37^{\circ} \mathrm{C}$. DNA samples and 8-oxodG standards were mixed with anti-8oxodG monoclonal solution in a 96-well plate and incubated for $1 \mathrm{~h}$ at $25^{\circ} \mathrm{C}$. Wells were washed with PBS/0.1\% Tween 20 and goat anti-mouse IgG-HRP conjugate antibody was added and incubated for another hour. Finally, TACSSapphire was added for 15 minutes at $25^{\circ} \mathrm{C}$. The reaction was stopped by $0.2 \mathrm{M} \mathrm{HCl}$ and the absorbance was immediately read by a multiplate reader at $450 \mathrm{~nm}$.

\section{Statistical analyses}

Statistical differences between samples were tested with one-way ANOVA and post hoc comparisons performed with Dunnett's method, by using SigmaStat 3.1 software. For the analysis of the mitotic cells and of p53/pp53 and Chk2/pChk2 paired $t$-test was used. Statistical differences were considered to be significant at the $95 \%$ level $(\mathrm{p}<0.05)$.

\section{Additional file}

Additional file 1: DNA adduct formation in BEAS-2B cells exposed to $7.5 \mu \mathrm{g} / \mathrm{cm}^{2}$ of PM organic extract and $15 \mu \mathrm{M} \mathrm{BaP}$ for 3 and $24 \mathrm{~h}$. Representative autoradiograms showing DNA adduct profiles. The origin, at the bottom left-hand corner, was cut off before exposure. The arrow shows 10-(deoxyguanosin- $N^{2}$-yl)-7,8,9-trihydroxy-7,8,9,10-tetrahydro-BaP (dG- $\left.N^{2}-B P D E\right)$.

\section{Abbreviations}

NAC: N-acetyl cysteine; Thio: Thiourea; a-NF: a-naphthoflavone; M/A: Metaphase/anaphase transition point; ROS: Reactive oxygen species; PM: Particulate matter; CB: Carbon black; MN: Micronuclei; Etop: Etoposide.

\section{Competing interests}

The authors declare that they have no competing interests.

\section{Authors' contributions}

EL performed the experiments and manuscript writing. KBG supervised the comet assay procedure and results analysis. VMA and JEK conducted the ${ }^{32}$ P-postlabelling assay. VMA, JEK and MC helped with the writing of the manuscript. JAH and MG defined the experimental plan, supervised all the experiments, interpreted the results and contributed to writing the manuscript. All authors read and approved the final manuscript.

\section{Acknowledgement}

This study has been supported by Cariplo Foundation (TOSCA project). VMA is supported by Cancer Research UK. JEK is supported by the Wellcome Trust. EL also wants to thank Dr PE Schwarze and Dr G Brunborg for providing excellent laboratory facilities during her visit as guest scientist at the Norwegian Institute of Public Health. The technical assistance of $\mathrm{HJ}$ Dahlman and L Ekren is also acknowledged.

\section{Author details}

'Department of Environmental Sciences, POLARIS Research Centre, University Milano-Bicocca, Piazza della Scienza 1, 20126 Milano, Italy. ${ }^{2}$ Division of Environmental Medicine, Norwegian Institute of Public Health, P.O. Box 4404, Nydalen N-0403 Oslo, Norway. ${ }^{3}$ Analytical and Environmental Sciences Division, MRC-PHE-Centre for Environment and Health, King's College London, 150 Stamford Street, London, SE1 9NH, UK.

Received: 6 May 2013 Accepted: 25 November 2013

Published: 19 December 2013

\section{References}

1. Loomis D, Grosse Y, Lauby-Secretan B, Ghissassi FE, Bouvard V, Benbrahim-Tallaa L, Guha N, Baan R, Mattock H, Straif K, on behalf of IARC: The carcinogenicity of outdoor air pollution. Lancet Oncol 2013, 14(13):1262-1263.

2. de Kok TM, Driece HAL, Hogervorst JGF, Briedé JJ: Toxicological assessment of ambient and traffic-related particulate matter: a review of recent studies. Mutat Res 2006, 613:103-122.

3. Englert N: Fine particles and human health - a review of epidemiological studies. Toxicol Lett 2004, 149:235-242.

4. Donaldson K, Stone V, Borm PJA, Jimenez LA, Gilmour PS, Schins RPF, Knaapen AM, Rahman I, Faux SP, Brown DM, Macnee W: Oxidative stress and calcium signaling in the adverse effects of environmental particles (PM10). Free Radic Biol Med 2003, 34(11):1369-1382.

5. Pope CA III, Dockery DW: Health effects of fine particulate air pollution: lines that connect. J Air \& Waste Manage Assoc 2006, 56:709-742.

6. Brook RD, Rajagopalan S, Pope CA III, Brook JR, Bhatnagar A, Diez-Roux AV, Holguin F, Hong Y, Luepker RV, Mittleman MA, Peters A, Siscovick D, Smith SC, Whitsel L, Kaufman JD: Particulate matter air pollution and cardiovascular disease: an update to the scientific statement from the American heart association. Circulation 2010, 121:2331-2378.

7. Pope CA III, Burnett RT, Turner MC, Cohen A, Krewski D, Jerrett M, Gapstur SM, Thun MJ: Lung cancer and cardiovascular disease mortality associated with ambient air pollution and cigarette smoke: shape of the exposure-response relationships. Environ Health Perspect 2011, 119:1616-1621.

8. Pope CA III, Burnett RT, Thun MJ, Calle EE, Krewski D, Ito K, Thurston GD: Lung cancer, cardiopulmonary mortality and long-term exposure to fine particulate air pollution. JAMA 2002, 287:1132-1141.

9. Murr LE, Esquivel EV, Bang JJ: Characterization of nanostructure phenomena in airborne particulate aggregates and their potential for respiratory health effects. J Mater Sci Mater Med 2004, 15:237-247.

10. Kocbach A, Johansen BV, Schwarze PE, Namork E: Analytical electron microscopy of combustion particles: a comparison of vehicle exhaust and residential wood smoke. Sci Total Environ 2005, 346:231-243.

11. Alfaro-Moreno E, Martinez L, Garcia-Cuellar C, Bonner JC, Murray JC, Rosas Rosales SP, Osornio-Vargas AR: Biologic effects induced in vitro by PM10 from three different zones of Mexico City. Environ Health Perspect 2002, 110:715-720.

12. Soukup JM, Becker S: Human alveolar macrophage responses to air pollution particulates are associated with insoluble components of coarse material, including particulate endotoxins. Toxicol Appl Pharmacol 2001, 171:20-26. 
13. Chung W, Ossamor O, Sharifi V, Swithenbank J: Characterisation of Airborne particulate matter in a city environment. J Mod App/ Sci 2008, 2:17-32.

14. Hetland R, Cassee F, Lag M, Refsnes M, Dybing E, Schwarze P: Cytokine release from alveolar macrophages exposed to ambient particulate matter: heterogeneity in relation to size, city and season. Part Fibre Toxicol 2004, 2:4

15. Billet $S$, Abbas I, Le Goff J, Verdin A, Andrè V, Lafargue PE, Hachimi A, Cazier F, Sichel F, Shirali P, Garcon G: Genotoxic potential of polycyclic aromatic hydrocarbons-coated onto airborne particulate matter (PM2.5) in human lung epithelial A549 cells. Cancer Lett 2008, 270:144-155.

16. de Kok TM, Hogervorst JG, Briede JJ, van Herwijnen MH, Maas LM, Moonen EJ, Driece HA, Kleinjans JC: Genotoxicity and physicochemical characteristics of traffic-related ambient particulate matter. Environ $\mathrm{Mol}$ Mutagen 2005, 46:71-80.

17. Don Porto Carero A, Hoet PHM, Verschaeve L, Schoeters G, Nemery B: Genotoxic effects of carbon black particles, diesel exhaust particles, and urban air particulates and their extracts on a human alveolar epithelial cell line (A549) and a human monocytic cell line (THP-1). Environ Mol Mutagen 2001, 37:155-163.

18. Hsiao WL, Mo ZY, Fang M, Shi XM, Wang F: Cytotoxicity of PM(2.5) and PM (2.5-10) ambient air pollutants assessed by the MTT and the Comet assays. Mutat Res 2000, 471:45-55.

19. Poma A, Limongi T, Pisani C, Granato V, Picozzi P: Genotoxicity induced by fine urban air particulate matter in the macrophages cell line RAW 264.7. Toxicol In Vitro 2006, 20:1023-1029.

20. Kocbach A, Herseth Jl, Låg M, Refsnes M, Schwarze PE: Particles from wood smoke and traffic induce differential pro-inflammatory response patterns in co-cultures. Toxicol Appl Pharmacol 2008, 232:317-326.

21. Gualtieri M, Ovrevik J, Mollerup S, Asare N, Longhin E, Dahlman HJ, Camatini M, Holme JA: Airborne urban particles (Milan winter-PM2.5) cause mitotic arrest and cell death: Effects on DNA, mitochondria, AhR binding and spindle organization. Mutat Res 2011, 713(1-2):18-31.

22. Deng $F$, Guo $X$, Liu H, Fang $X$, Yang $M$, Chen W: Effects of dust storm PM2.5 on cell proliferation and cell cycle in human lung fibroblasts. Toxicol In Vitro 2007, 21:632-638.

23. Jalava PI, Salonen RO, Pennanen AS, Sillanpää M, Hälinen Al, Happo MS, Hillamo R, Brunekreef B, Katsouyanni K, Sunyer J, Hirvonen MR: Heterogeneities in inflammatory and cytotoxic responses of RAW 264.7 macrophage cell line to urban air coarse, fine, and ultrafine particles from six European sampling campaigns. Inhal Toxicol 2007, 19:213-225.

24. Rieder $C L$ : Mitosis in vertebrates: the $G 2 / M$ and $M / A$ transitions and their associated checkpoints. Chromosome Res 2011, 19:291-306.

25. Okada H, Mak TW: Pathways of apoptotic and non-apoptotic death in tumour cells. Nat Rev Cancer 2004, 4:592-603.

26. Pearce AK, Humphrey TC: Integrating stress-response and cell-cycle checkpoint pathways. Trends Cell Biol 2001, 11(10):426-433.

27. Branzei D, Foiani M: Regulation of DNA repair throughout the cell cycle. Mol Cell Biol 2008, 9:297-308.

28. Wang Y, Ji P, Liu J, Broaddus RR, Xue F, Zhang W: Centrosome-associated regulators of the $\mathrm{G} 2 / \mathrm{M}$ checkpoint as targets for cancer therapy. Mol Cancer 2009, 8:8-21.

29. Castedo M, Perfettini JL, Roumier T, Andreau K, Medema R, Kroemer G: Cell death by mitotic catastrophe: a molecular definition. Oncogene 2004, 23:2825-2837.

30. Fukasawa K: p53, cyclin-dependent kinase and abnormal amplification of centrosomes. Biochim Biophys Acta 2008, 1786:15-23.

31. McNeely SC, Taylor BF, States JC: Mitotic arrest-associated apoptosis induced by sodium arsenite in A375 melanoma cells is BUBR1-dependent. Toxicol Appl Pharmacol 2008, 231(1):61-67

32. Soberanes S, Urich D, Baker CM, Burgess Z, Chiarella SE, Bell EL, Ghio AJ, De Vizcaya-Ruiz A, Liu J, Ridge KM, Kamp DW, Chandel NS, Schumacker PT, Mutlu GM, Budinger GRS: Mitochondrial complex III-generated oxidants activate ASK1 and JNK to induce alveolar epithelial cell death following exposure to particulate matter air pollution. J Biol Chem 2009, 284:2176-2186.

33. Abbas I, Garcon G, Saint-Georges F, Billet S, Verdin A, Gosset P, Mulliez $P$, Shirali $P$ : Occurrence of molecular abnormalities of cell cycle in L132 cells after in vitro short-term exposure to air pollution PM2.5. Chem Biol Interact 2010, 188:558-565.
34. Zhang J, Ghio AJ, Gao M, Wei K, Rosen GD, Upadhyay D: Ambient particulate matter induces alveolar epithelial cell cycle arrest: Role of G1 cyclins. FEBS Lett 2007, 581:5315-5320.

35. Berglind $H$, Pawitan $Y$, Kato $S$, Ishioka C, Soussi T: Analysis of p53 mutation status in human cancer cell lines: a paradigm for cell line crosscontamination. Cancer Biol Ther 2008, 7(5):699-708.

36. Ding J, He G, Gong W, Wen W, Sun W, Ning B, Huang S, Wu K, Huang C, Wu M, Xie W, Wang H: Effects of nickel on cyclin expression cell cycle progression and cell proliferation in human pulmonary cells. Cancer Epidemiol Biomarkers Prev 2009, 18:1720.

37. Totlandsdal Al, Cassee FR, Schwarze P, Refsnes M, Låg M: Diesel exhaust particles induce CYP1A1 and pro-inflammatory responses via differential pathways in human bronchial epithelial cells. Part Fibre Toxicol 2010, 7:41.

38. Balakrishna S, Lomnicki S, McAvey KM, Cole RB, Dellinger B, Cormier SA: Environmentally persistent free radicals amplify ultrafine particle mediated cellular oxidative stress and cytotoxicity. Part Fibre Toxicol 2009, $6: 11$.

39. Glowala M, Mazurek A, Piddubnyak V, Fiszer-Kierzkowska A, Michalska J, Krawczyk Z: HSP70 overexpression increases resistance of V79 cells to cytotoxicity of airborne pollutants, but does not protect the mitotic spindle against damage caused by airborne toxins. Toxicology 2001, 170:211-219.

40. Acilan C, Saunders WS: A tale of too many centrosomes. Cell 2008 134:572-575.

41. Echard $\mathrm{A}, \mathrm{O}^{\prime}$ Farrell $\mathrm{PH}$ : The degradation of two mitotic cyclins contributes to the timing of cytokinesis. Curr Biol 2003, 13:373-383.

42. Burns TF, Fei P, Scata KA, Dicker DT, El-Deiry WS: Silencing of the novel p53 target gene Snk/PIk2 leads to mitotic catastrophe in paclitaxel (taxol)-exposed cells. Mol Cell Biol 2003, 23:5556-5571.

43. Brito DA, Rieder CL: Mitotic checkpoint slippage in humans occurs via cyclin B destruction in the presence of an active checkpoint. Curr Biol 2006, 16:1194-1200.

44. Gualtieri M, Øvrevik J, Holme JA, Perrone MG, Bolzacchini E, Schwarze PE, Camatini M: Differences in cytotoxicity versus pro-inflammatory potency of different PM fractions in human epithelial lung cells. Toxicol In Vitro 2010, 24:29-39.

45. Chakra ORA, Joyeux M, Nerriere E, Strub M, Zmirou-Navier D: Genotoxicity of organic extracts of urban airborne particulate matter: An assessment within a personal exposure study. Chemosphere 2007, 66:1375-1381.

46. Nel AE, Diaz-Sanchez D, Li N: The role of particulate pollutants in pulmonary inflammation and asthma: evidence for the involvement of organic chemicals and oxidative stress. Curr Opin Pulm Med 2001, 7:20-26.

47. Billet S, Garçon G, Dagher Z, Verdin A, Ledoux F, Cazier F, Courcot D, Aboukais A, Shirali P: Ambient particulate matter (PM2.5): physicochemical characterization and metabolic activation of the organic fraction in human lung epithelial cells (A549). Environ Res 2007, 105:212-223.

48. Sevastyanova O, Binkova B, Topinka J, Srama RJ, Kalina I, Popov T, Novakova Z, Farmer PB: In vitro genotoxicity of PAH mixtures and organic extract from urban air particles Part II: Human cell lines. Mutat Res 2007, 620:123-134.

49. Binkova B, Cerna M, Pastorovka A, Jelınek R, Benes I, Novak J, Sram RJ: Biological activities of organic compounds absorbed onto ambient air particles: comparison between the cities of teplice and prague during the summer and winter seasons 2000-2001. Mutat Res 2003, 525:43-59.

50. Möller W, Hofer T, Ziesenis A, Karg E, Heyder J: Ultrafine particles cause cytoskeletal dysfunctions in macrophages. Toxicol Appl Pharmacol 2002, 182:197-207.

51. Dong L, Yang WM: Effect of different organic extracts of ambient particulate matter on cell cycle in human blood lymphocyte. J Toxicol 2005, 19:221-223.

52. Baird WM, Kaspin C, Kudla K, Seidel A, Greim H, Luch A: Relationship of dibenzo[a, I]pyrene-DNA binding to the induction of p53, p21(WAF1) and cell cycle arrest in human cells in culture. Polycycl Aromat Comp 1999, 16:119-129.

53. Binkova B, Giguere $Y$, Rossner $P$, Dostal M, Sram RJ: The effect of dibenzo[a, I] pyrene and benzo[a]pyrene on human diploid lung fibroblasts: the induction of DNA adducts, expression of $\mathrm{p} 53$ and p21WAF1 proteins and cell cycle distribution. Mutat Res 2000, 471:57-70.

54. Hockley SL, Arlt VM, Brewer D, Giddings I, Phillips DH: Time- and concentration-dependent changes in gene expression induced by benzo 
(a)pyrene in two human cell lines, MCF-7 and HepG2. BMC Genomics 2006, 7:260.

55. Hamouchene H, Arlt VM, Giddings I, Phillips DH: Influence of cell cycle on responses of MCF-7 cells to benzo[a]pyrene. BMC Genomics 2011, 12:333.

56. Seoane Al, Dulout FN: Genotoxic ability of cadmium, chromium and nickel salts studied by kinetochore staining in the cytokinesis-blocked micronucleus assay. Mutat Res 2001, 490:99-106.

57. Rossman TG: Mechanism of arsenic carcinogenesis: an integrated approach. Mutat Res 2003, 533:37-65.

58. Li N, Xia T, Nel AE: The role of oxidative stress in ambient particulate matter-induced lung diseases and its implications in the toxicity of engineered nanoparticles. Free Radic Biol Med 2008, 44:1689-1699.

59. Schwarze PE, Øvrevik J, Låg M, Refsnes M, Nafstad P, Hetland RB, Dybing E: Particulate matter properties and health effects: consistency of epidemiological and toxicological studies. Hum Exp Toxicol 2006 25:559-579.

60. Genter MB, Clay CD, Dalton TP, Dong H, Nebert DW, Shertzer HG: Comparison of mouse hepatic mitochondrial versus microsomal cytochromes P450 following TCDD treatment. Biochem Biophys Res Commun 2006, 342:1375-1381.

61. Burczynski ME, Penning TM: Nuclear translocation of the aryl hydrocarbon receptor generated by aldo-keto reductases induce CYP1A1 via genotoxic polycyclic aromatic hydrocarbon ortho-quinones. Cancer Res 2000, 60:908-915

62. Abbas I, Garçon G, Saint-Georges F, Andre V, Gosset P, Billet S, Le Goff J, Verdin A, Mulliez P, Sicheld F, Shirali P: Polycyclic aromatic hydrocarbons within airborne particulate matter (PM2.5) produced DNA bulky stable adducts in a human lung cell coculture model. J Appl Toxicol 2011, 33(2):109-119.

63. Gualtieri M, Longhin E, Mattioli M, Mantecca P, Tinaglia V, Mangano E, Proverbio MC, Sestetti G, Camatini M, Battaglia C: Gene expression profiling of A549 cells exposed to Milan PM2.5. Toxicol Lett 2012, 209(2):136-145.

64. Andrysik Z, Vondráček J, Marvanová S, Ciganek M, Neča J, Pěnčíková K, Mahadevan B, Topinka J, Baird WM, Kozubík A, Machala M: Activation of the aryl hydrocarbon receptor is the major toxic mode of action of an organic extract of a reference urban dust particulate matter mixture: the role of polycyclic aromatic hydrocarbons. Mutat Res 2011, 714:53-62

65. Knaapen AM, Borm PJA, Albrecht C, Schins RPF: Inhaled Particles And Lung Cancer. Part A: Mechanisms. Int J Cancer 2004, 109:799-809.

66. Woodbine L, Brunton H, Goodarzi AA, Shibata A, Jeggo PA: Endogenously induced DNA double strand breaks arise in heterochromatic DNA regions and require ataxia telangiectasia mutated and Artemis for their repair. Nucleic Acids Res 2011, 39(16):6986-6997.

67. Park JH, Mangal D, Frey AJ, Harvey RG, Blair IA, Penning TM: Aryl hydrocarbon receptor facilitates DNA strand breaks and 8-Oxo-2-deoxyguanosine formation by the Aldo-Keto reductase product Benzo[a]pyrene-7,8-dione. J Biol Chem 2009, 284(43):29725-29734.

68. Shimada T, Guengerich FP: Inhibition of human cytochrome P450 1A1-, $1 \mathrm{~A} 2-$, and 1B1-mediated activation of procarcinogens to genotoxic metabolites by polycyclic aromatic hydrocarbons. Chem Res Toxicol 2006, 19:288-294.

69. Kain J, Karlsson HL, Möller L: DNA damage induced by micro- and nanoparticles -interaction with FPG influences the detection of DNA oxidation in the comet assay. Mutagenesis 2012, 27(4):491-500.

70. Valavanidis A, Vlachogianni T, Fiotakis C: 8-hydroxy-2' -deoxyguanosine (8-OHdG): A Critical Biomarker of Oxidative Stress and Carcinogenesis. J Environ Sci Health 2009, 27(2):120-139.

71. Prahalad AK, Inmon J, Dailey LA, Madden MC, Ghio AJ, Gallagher JE: Air pollution particles mediated oxidative DNA base damage in a cell free system and in human airway epithelial cells in relation to particulate metal content and bioreactivity. Chem Res Toxicol 2001, 14:879-887.

72. Hanzalova K, Rossner P, Sram RJ: Oxidative damage induced by carcinogenic polycyclic aromatic hydrocarbons and organic extracts from urban air particulate matter. Mutat Res 2010, 696:114-121.

73. Schwarze PE, Totlandsdal Al, Låg M, Refsnes M, Holme LA, Øvrevik J: Inflammation-related effects of diesel engine exhaust particles: studies on lung cells in vitro. Biomed Res Int 2013. doi:10.1155/2013/685142.

74. Gualtieri M, Manteca P, Corvaja V, Longhin E, Perrone MG, Bolzacchini E, Camatini M: Winter fine particulate matter from Milan induces morphological and functional alterations in human pulmonary epithelial cells (A549). Toxicol Lett 2009, 188(1):52-62.

75. Perrone MG, Gualtieri M, Ferrero L, Lo Porto C, Udisti R, Bolzacchini E, Camatini M: Seasonal variations in chemical composition and in vitro biological effects of fine PM from Milan. Chemosphere 2010, 78:1368-1377

76. Mantecca P, Gualtieri M, Longhin E, Bestetti G, Palestini P, Bolzacchini E, Camatini M: Adverse biological effects of Milan urban PM looking for suitable molecular markers of exposure. CICEQ 2012, 18:635-641.

77. Schmeiser HH, Stiborova M, Arlt VM: ${ }^{32}$ P-postlabeling analysis of DNA adducts. Methods Mol Biol 2013, 1044:389-401.

78. Kim SI, Arlt VM, Yoon Jl, Cole KJ, Pfeifer GP, Phillips DH, Besaratinia A: Whole body exposure of mice to secondhand smoke induces dose-dependent and persistent promutagenic DNA adducts in the lung. Mutat Res 2011, 716:92-98. Erratum in Mutat. Res. 2013, 745-746: 55-56.

79. Siddens LK, Larkin A, Krueger SK, Bradfield CA, Waters KM, Tilton SC, Pereira CB, Löhr CV, Arlt VM, Phillips DH, Williams DE, Baird WM: Polycyclic aromatic hydrocarbons as skin carcinogens: comparison of benzo[a] pyrene, dibenzo[def, p]chrysene and three environmental mixtures in the FVB/N mouse. Toxicol Appl Pharmacol 2012, 264(3):377-386.

\section{doi:10.1186/1743-8977-10-63}

Cite this article as: Longhin et al:: Cell cycle alterations induced by urban PM2.5 in bronchial epithelial cells: characterization of the process and possible mechanisms involved. Particle and Fibre Toxicology 2013 10:63.

\section{Submit your next manuscript to BioMed Central and take full advantage of:}

- Convenient online submission

- Thorough peer review

- No space constraints or color figure charges

- Immediate publication on acceptance

- Inclusion in PubMed, CAS, Scopus and Google Scholar

- Research which is freely available for redistribution 